
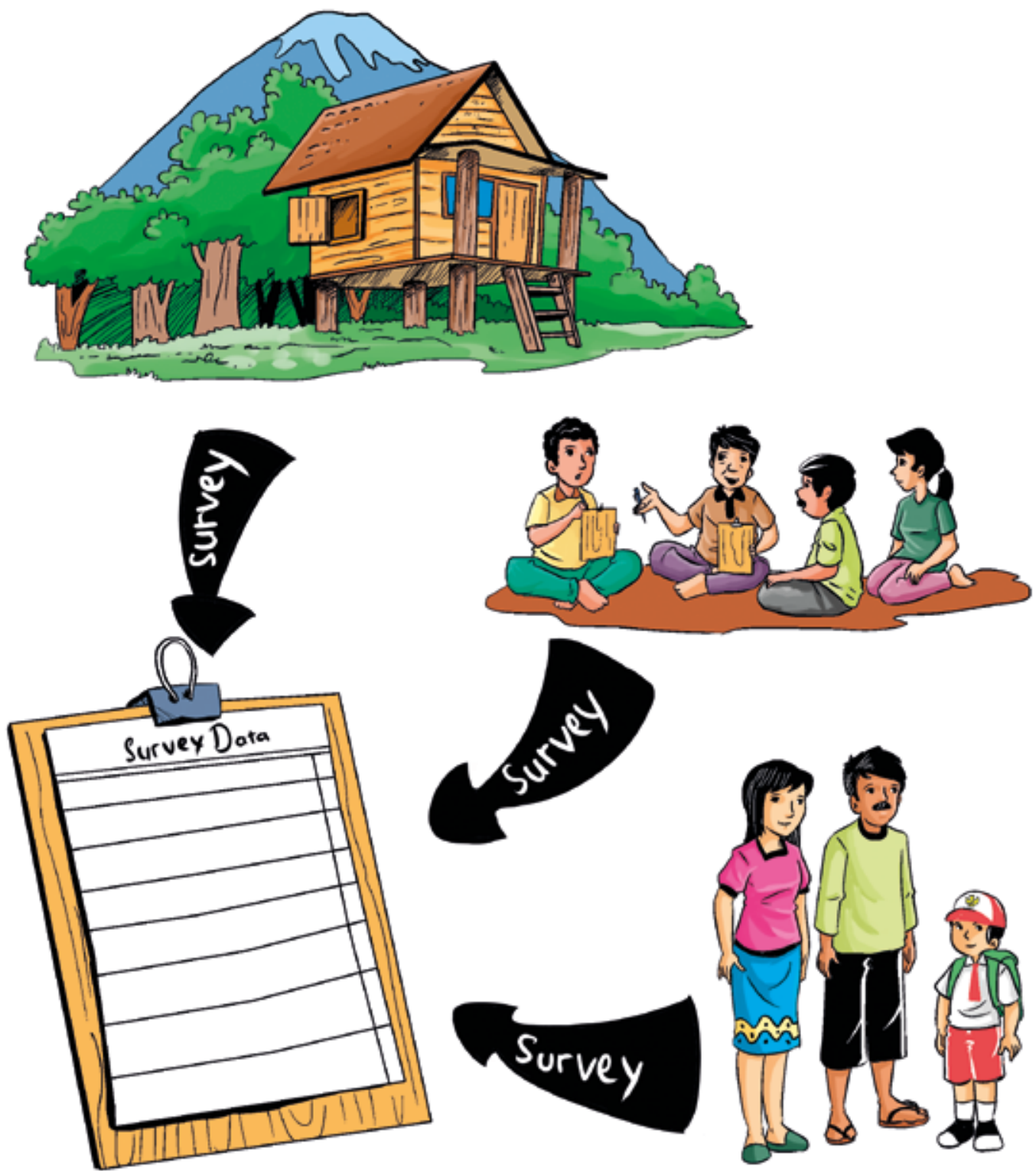

Practical guide for socio-economic livelihood, land tenure and rights surveys for use in collaborative ecosystem-based land use planning

Nining Liswanti, Bayuni Shantiko, Emily Fripp, Esther Mwangi and Yves Laumonier

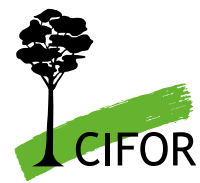





\section{Practical guide for socio-economic livelihood, land tenure and rights surveys for use in collaborative ecosystem-based land use planning}

Nining Liswanti

CIFOR

Bayuni Shantiko

CIFOR

Emily Fripp

EFECA

Esther Mwangi

CIFOR

Yves Laumonier

CIRAD-CIFOR 
๑ 2012 Center for International Forestry Research

All rights reserved

ISBN 978-602-8693-89-9

Liswanti, N., Shantiko, B., Fripp, E., Mwangi, E. and Laumonier, Y. 2012 Practical guide for socio-economic livelihood, land tenure and rights surveys for use in collaborative ecosystembased land use planning. CIFOR, Bogor, Indonesia.

Illustration by Pandu Dharma Wijaya (TELAPAK)

\author{
CIFOR \\ Jl. CIFOR, Situ Gede \\ Bogor Barat 16115 \\ Indonesia \\ $\mathrm{T}+62(251) 8622-622$ \\ $\mathrm{F}+62(251) 8622-100$ \\ E cifor@cgiar.org
}

\title{
cifor.org
}

Any views expressed in this publication are those of the authors. They do not necessarily represent the views of CIFOR, the authors' institutions or the financial sponsors of this publication. 


\section{Table of contents}

Part A: The approach 1

Aim of this guide 1

What is collaborative land use planning? $\quad 2$

Part B: Undertaking socio-economic surveys 3

Step 1 - Survey design, sampling and data requirements 3

Step 2 - Planning and training the team 5

Step 3 - Implementation $\quad 7$

Part C: Using the data collected 11

Step 1 - Data analysis $\quad 12$

Step 2 - Using the results 13

$\begin{array}{ll}\text { Supporting Notes } 1 \text { to } 9 & 15\end{array}$

$\begin{array}{ll}\text { Note } 1 \text { - Key definitions } & 16\end{array}$

Note 2 - Sampling techniques 18

Note 3 - Choosing the most appropriate type of question format 21

Note 4 - Conducting the survey 25

Note 5 - Guidance for community meetings 27

Note 6 - Interview techniques 29

Note 7 - Focus group discussions 31

Note 8 - Example questionnaire templates: Household, village and key informant 36

Note 9 - Experiences from the CoLUPSIA project 85

Resources $\quad 91$

$\begin{array}{ll}\text { Websites } & 92\end{array}$ 


\section{List of figures, tables and boxes}

\section{Figures}

1 Developing and implementing the survey 3

2 Study villages in the four pilot areas in Kapuas Hulu, West Kalimantan 88

3 Study villages in the five pilot areas in Central Maluku

(Seram Island), Maluku

\section{Tables}

1 Advantages and disadvantages of open questions

2 Advantages and disadvantages of partially open questions 23

3 Advantages and disadvantages of closed questions 24

4 Examples of themes and topics for discussion in FGDs 32

5 Socio-economic data required for collaborative land use planning $\quad 90$

\section{Boxes}

1 An example of a briefing note used to introduce the survey team to a village

2 Interview guide

3 The role of facilitator 


\section{Part A: The approach}

Understanding the socio-economic conditions, land tenure and rights of communities is a critical aspect of collaborative land use planning.

\section{Aim of this guide}

This guide aims to provide practical steps for field-based practitioners to follow in conducting socio-economic surveys of households and villages, including focus group discussions and key informant interviews. This guide is accompanied by nine Supporting Notes. These are essential tools for gathering socio-economic information, the results of which can be used as input to collaborative land use decision-making tools and procedures.

Socio-economic survey tools are designed to collect information as a means of improving understanding of local resource management systems, resource use and the relative importance of resources for households and villages. Surveys also provide information on interaction with the government decision-making systems and community perceptions of trends and priority issues. Knowledge about community-based institutions, which is also obtained, and their roles in the sustainable use and conservation of natural resources, helps to facilitate or reinforce a consensus on land tenure and rights for the region, now and in the future.




Thus, the use of these tools also serves to highlight possible avenues for conflict resolution between stakeholders. Conflicts over resources often arise in the absence of a clear boundary and respect for institutional arrangements for the land.

\section{What is collaborative land use planning?}

Collaborative land use planning involves working with all stakeholders government, local communities, private sector and other relevant individuals - to ensure that the land is used sustainably, avoiding negative impacts or threats from environmental degradation and forest loss while ensuring that the social and economic considerations of all users are accounted for. With particular respect to communities, collaborative land use planning therefore has the following aim:

\section{To ensure that land use planning decisions are made with consideration of local communities' opinions, land use needs and socio-economic conditions (opportunities and constraints), including rights of access to and use of land.}

The first step in this process is to engage local communities. This can be achieved through the use of household and village surveys, in conjunction with focus group discussions. This is an important way of positively engaging local stakeholders in the planning process and in ensuring that local voices are heard. Surveys and focus group discussions also provide a way to gain a thorough understanding of local people's relationship with the relevant resources - economic and social - and their legal rights and access to the use of resources. This information is imperative for effective land use planning, that is, planning that will work in practice and that meets local needs, thus potentially avoiding conflict among people over resources. Key terms are defined in Supporting Note 1.






\section{Part B: Undertaking socio- economic surveys}

Undertaking household and village surveys and focus group discussions in order to understand livelihoods, tenure and rights
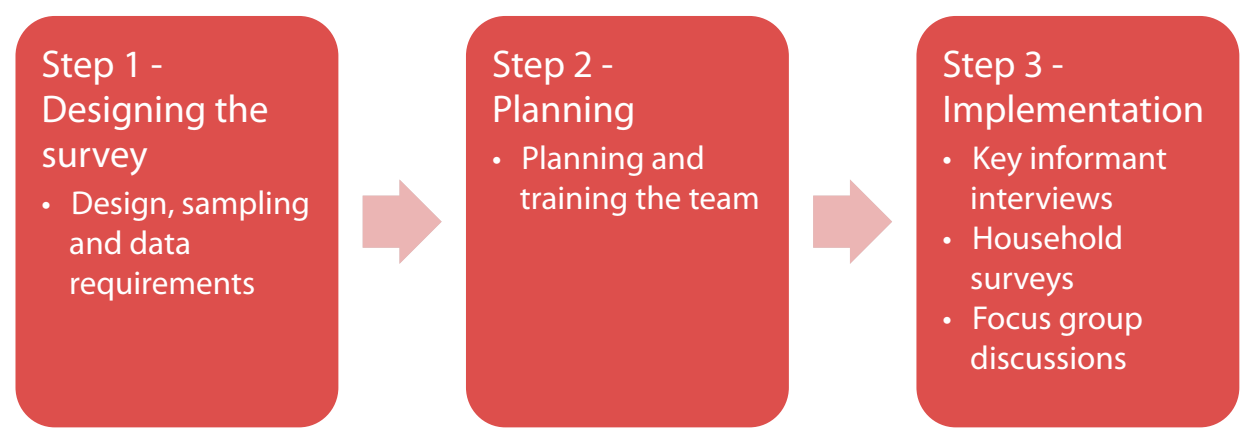

Figure 1. Developing and implementing the survey

\section{Step 1 - Survey design, sampling and data requirements}

When conducting a survey, the first step is to determine the objective and purpose of the survey. This will provide the framework for the content and scope of the survey work and be used to help identify which kinds of stakeholders and communities are to be surveyed.

\section{Data requirements and survey design}

The data to be gathered through the survey process will need to reflect the purpose of the survey work. In developing the survey, other considerations are the length of time for the interview and thus the resources (financial, human) needed to effectively conduct the surveys, enter the data and analyse the results.

Different tools (surveys, discussions, interviews) are used to obtain different types of information from different groups of informants. For example, household surveys can be used to gather information on age, gender, education, income sources (agriculture, forest and employment), perceptions of change in land use and access to forest resources. By contrast, understanding of the functions (governance and institutional) of the village, development, broader issues on access to land, population growth, social conditions and constraints can be gained through focus group discussions and interviews with key informants. These survey methods are explained in Step 3: Implementation. 




\section{Who should be included in the survey(s)?}

The individuals and communities to be surveyed should be decided when considering the objectives and purpose of the survey. Different individuals or groups of individuals will be interviewed depending on the data needed. For a household-level survey, a representative of the household should be interviewed, but the village head or traditional leader will be interviewed in a key informant interview. Focus group discussions will include members of the community, with groups formed based on age and gender. More details are in the sections below.

\section{Random sampling and sample size}

The sample size needs to be sufficient to ensure that the survey results will be statistically relevant. However, in many cases, the sample size also has to be balanced with the available resources - financial, human and time.

Random sampling is used to ensure that the sample is representative of the study area, while avoiding bias in the results and ensuring that all elements of the population have an equal chance of being interviewed. There are a number of approaches to determining a random sample, e.g. systematic, stratified and 
clusters. For the purposes of collaborative land use planning, a simple random sample approach is sufficient (Supporting Note 2).

\section{Types of questions}

For all interview types (household interviews, focus groups and key informants), questions can be structured and asked as open, closed or partially open questions. The type of question used will depend on the information that is being gathered. There are advantages and disadvantages of all question types (Supporting Note 3).

Through an open question, such as 'Why has the paddy rice harvest declined this year?', the interviewer can uncover the meaning behind an answer, allowing respondents to provide examples and explain their answer. These questions are more time-consuming to administer and analyse. Open questions can be difficult to ask and interpreting the responses can be complex, so training is essential.

A partially open question, such as 'Consumption of forest products has increased, because ...' requires the respondent to elaborate on any answer given. The advantages of these questions are that they are quicker and easier to ask and to analyse than open questions, but the interviewer may miss some information because of the lack of an appropriate category or the level of detail in the response. To avoid these problems, the respondent's answers should be recorded in full, and the interview should repeat the question if the respondent has answered insufficiently.

Closed questions, such as multiple choices or yes/no answers, are used when key information is required, without the need for further explanation or in-depth understanding of the answer or issue. These questions are quick to ask and to analyse; however, the answers may result in a lack of depth and clarity.

\section{Step 2 - Planning and training the team}

A well-trained and experienced team is essential for the success of any socioeconomic survey. Previous practical experience is a great asset to the team, with relevant technical knowledge in socio-economics, forestry and natural resources, for example.

All members of the team will require rigorous and robust training in all types of survey (household, village, focus groups, key informant interviews) to be conducted. All members of the team should have a thorough understanding of the aims of the work and the meaning of every question to be asked. A combination of classroom and field-based training will provide the best understanding of survey 


methods and procedures. In addition, field training is very useful for checking the survey questions and means of data collection, thus providing an opportunity to make any necessary revisions to the survey and interview questions and procedures.

Consideration should also be given to the division of tasks between team members - facilitator, resource manager, observers/recorders, team leader.

Thorough preparation (designing the survey work, training the team, etc.) and scheduling the survey work are essential for a successful survey (Supporting Note 4). Preparation of the survey team and agreeing on the work plan and timeframe for completing the surveys should be finalised in advance. Villages should be given due notification prior to survey work and permission to conduct interviews should be sought and granted.

\section{Step 3 - Implementation}

Survey approaches vary. Different approaches are used for different purposes. For the purpose of collaborative land use planning, three survey methods are used:

- Key informant interviews

- Household surveys

- Focus group discussions

Before commencing any survey work, a community meeting should be held.

\section{Community meetings}

A community meeting is a valuable and productive way for the survey team to meet with the villagers, explain the survey work - its aims and approach - and ensure that all members of the community understand the expected outcomes of the survey work (Supporting Note 5). A decision to conduct a community meeting should be made only after meeting the community or village head. If possible, the village head can then help set up and conduct the community meeting.

\section{Key informant interviews}

Key informants are individuals who are deemed to have knowledge of particular issues. Key informants will provide the interview team with detailed information and, importantly, interpretation of key issues that other members of the community may not be able to provide. Potential key informants should be selected, in consultation with the village head, traditional leader or head of clan, for an in-depth interview with the survey team (Supporting Note 6). 




\section{Village and household surveys}

Village and household surveys are used predominantly to collect quantitative and qualitative data, through structured interviews with the head of the household, using both closed and open questions. Survey forms for both household- and village-level surveys are designed to gather specific information, relevant to the survey objective, as discussed above.

\section{Focus group discussions}

A focus group discussion aims to elicit in-depth information on the concepts, perceptions and ideas of a group of 6-12 people. Ideally, a focus group discussion is an iterative process, whereby each discussion builds on previous discussions by developing a topic or emphasis on certain aspects (Supporting Note 7).

In the context of a collaborative land use planning project, a focus group discussion could include discussions on institutional arrangements, community rights, community access to forest, the use of forest by the community and sustainable management of forest resources 


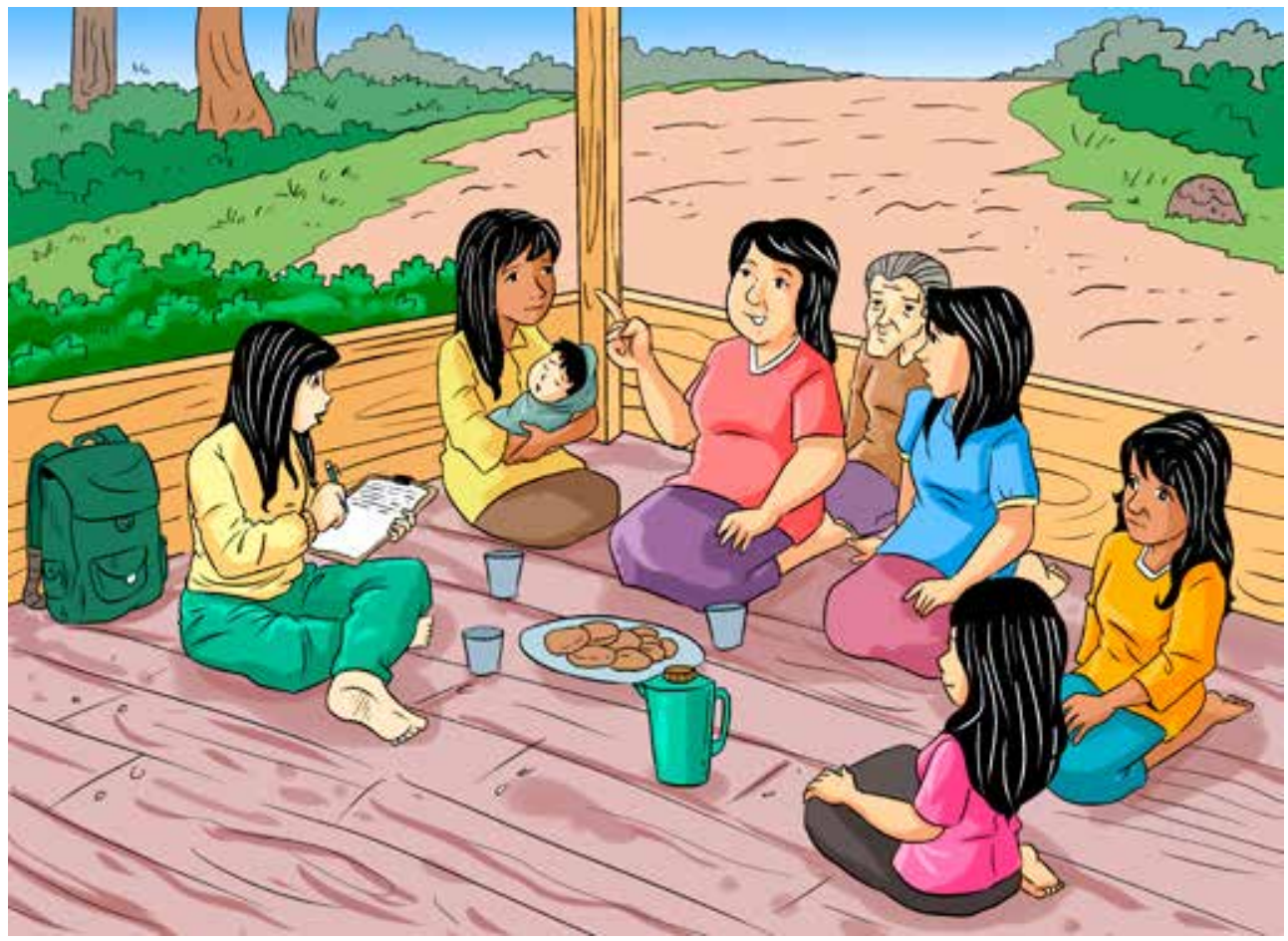

Key to the success of the focus group discussion is the presence of a strong facilitator who will stimulate discussion and ensure that it is aligned with the objectives of the survey team.

It is beneficial if other research instruments such as key informant interviews, indepth interviews or other qualitative techniques are used in conjunction with focus group discussions.

Survey forms used for household and village surveys, key informant interviews and focus group discussions are reproduced in Supporting Note 8. 



\section{Part C: Using the data collected}

Analysis and use of the collected data should reflect the objectives of the survey

The extent of analysis and use of the data collected will depend on the survey objectives and expected end uses. For collaborative land use planning, the survey results will provide, first, a robust baseline of socio-economic factors related to land resources and their use; and second, detailed insight into the community institutions, their relationship with land use planners (e.g. government bodies) and any potential areas of conflict. Together, this information can be used to develop collaborative land use decision-making tools.

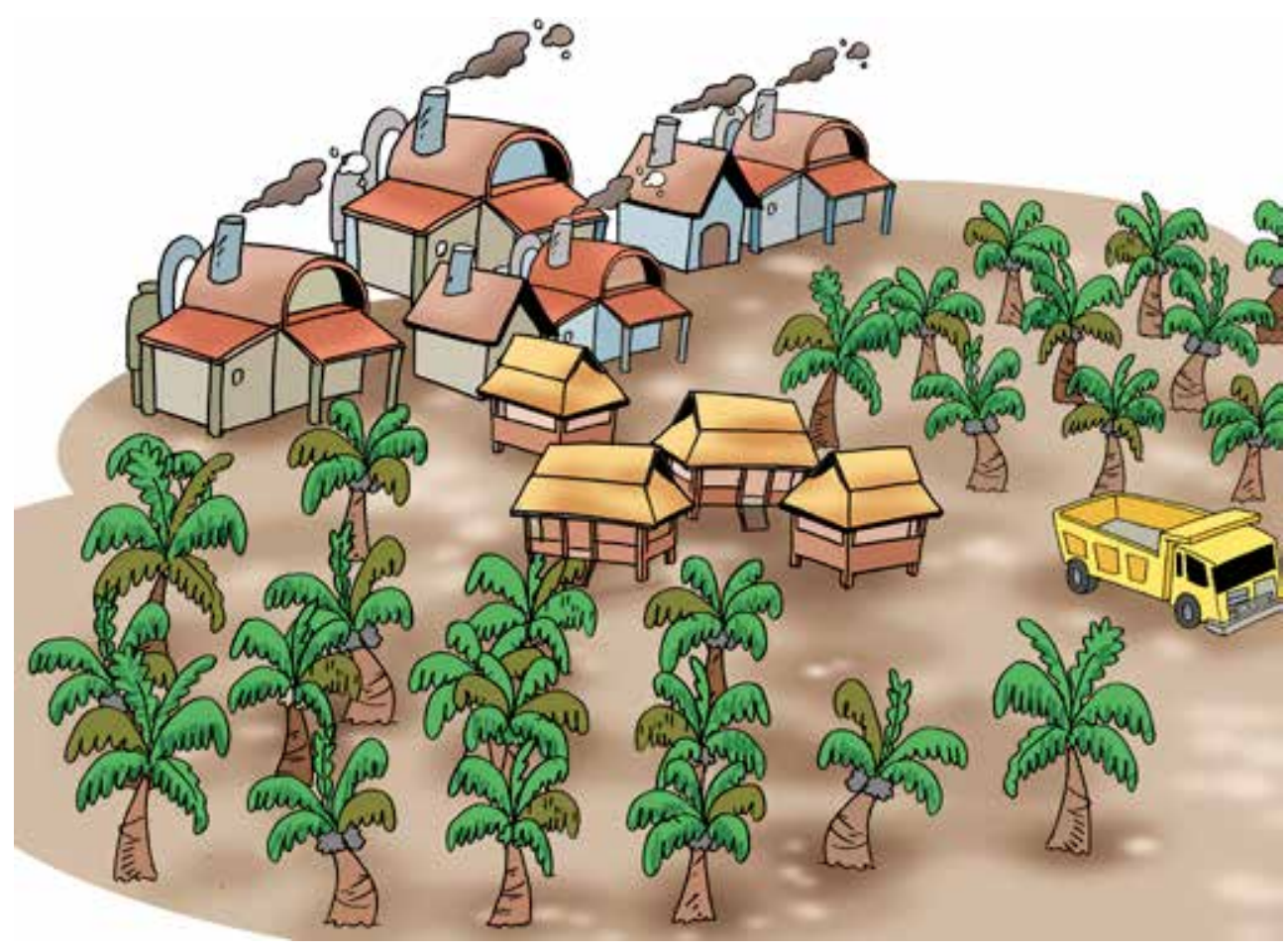




\section{Step 1 - Data analysis}

The choice of method for data analysis will depend on the volume of data collected and the expected uses of the findings.

Where household- and village-level surveys are conducted, significant volumes of data will be collected. Analysis of this volume of data is usually done in a statistical package such as SPSS. Using such packages also allows the data to be entered and cleaned before analysis. Data may be exported to other software packages such as Microsoft Excel for further analysis and for preparation of tables and graphs.

For more qualitative information, gathered, for example, from focus group discussions and key informant interviews, data analysis is based primarily on Glaser and Strauss's Grounded Theory Method. This method of analysis draws out a list of categories within and across the research question items and various sections of the survey instrument to identify key themes, separately for the focus group discussions and key informant interviews. The results are then imported into $\mathrm{nVivo}$, qualitative data analysis software. A hierarchical coding scheme is developed, based on the initial list of categories, to reflect the key research questions, and shape further by themes that emerge from the data. The data are then coded according to the themes identified. For the focus group discussions, to disaggregate findings by gender, age and location, the data are also coded using 'case' codes, with a separate 'node' created for each of the interviews. A range of advanced coding queries is used to analyse patterns, trends and responses to various questions in the survey. The results of the queries are exported into MS Word and analysed to write those parts of the report that summarise the findings and identify patterns and trends in the data.

The final analysis will need to reflect the original aims and objectives of the survey. To help structure the analysis, research questions can be developed, such as:

- How important is access to forest resources for the livelihoods of communities?

- Are the poorest communities more or less dependent on forest resources than other groups?

- How do access to forest resources and the resulting livelihood implications vary across the survey sample, e.g., a district?

- How do land ownership, tenure and user rights affect the livelihoods of communities? 


\section{Step 2 - Using the results}

The use of the results from the survey will again depend upon the objectives. For collaborative land use planning, the results will be used not only as baseline data but also to highlight the issues - constraints and opportunities - that communities encounter with regard to land use and the potential mechanisms for addressing these issues. Robust baseline data can be combined with biophysical data to provide a thorough overview of the situation within the study area (e.g. district). Understanding the communities and their internal and external (e.g. government bodies) relationships will provide a good foundation for developing processes for engaging communities in collaborative land use decision-making processes.

Experiences from CoLUPSIA are described in more detail in Supporting Note 9. 



\section{Supporting Notes 1 to 9}

\section{Purpose}

To support the 'Practical guide for socio-economic livelihood, land tenure and rights surveys for use in collaborative ecosystem-based land use planning', a series of Notes have been prepared. The Notes provide additional information and guidance, designed with the aim of assisting field practitioners in carrying out socio-economic surveys.

The Notes are based on experience gained from the CoLUPSIA project. They are not exhaustive in their content, but they aim to cover the key points identified and lessons learned during the course of the survey work completed in two districts (Kapuas Hulu and Central Maluku) in Indonesia, for 1366 households in total.

Together the Practical Guide and Supporting Notes, including examples of questionnaires used, form a Socio-economic Tool Kit. The Tool Kit is available on the CoLUPSIA website for download as a whole kit or as individual documents. 


\section{Note 1 - Key definitions}

To support the development of socio-economic questionnaires and administration of surveys, it is useful to fully understand the key terminology.

\section{Access to land}

'Access to land' can be simply defined as the ways in which people can have access to, or use, the land. In rural areas, land access is often based on custom, that is, local traditions and the ways in which community leaders assign land use rights to community members. Land access can also be obtained by purchasing, leasing, sharecropping, inheriting or squatting illegally on land.

\section{Closed questions}

A question format that limits respondents to a list of possible answers; closed questions can be answered with either a single word or a short phrase.

\section{Definition of 'forest'}

- Forest is a unit of ecosystem in the form of lands comprising biological resources, dominated by trees in their natural forms and environment, which cannot be separated from each other.

- Forest area is a certain area that is designated and/or stipulated by government to be retained as permanent forest.

- State forest is a forest located on lands subject to no ownership rights.

- Adat forest is a state forest located within a customary jurisdiction.

- Production forest is a forest area whose main function is to produce forest products.

- Protection forest is a forest area whose main function is to protect lifesupporting systems for hydrology, thus preventing floods, controlling erosion, preventing seawater intrusion and maintaining soil fertility.

- Conservation forest is a forest area with specific characteristics, with the main function of preserving plant and animal diversity and the forest ecosystem.

1 According to Law 41/1999 (Indonesia). 


\section{Household}

A 'household' is defined as 1) a group of people who live under one roof and have close or distant family relationships; 2) the use of one kitchen or stove where individuals eat together and share expenses for food and drink (more than $30 \%$ of individual incomes); or 3) a residence where a group of individuals share unpaid labour, production and consumption.

\section{Livelihood}

'Livelihood' refers to a person's capability to live, in terms of finances, food and assets.

\section{Land tenure and rights}

'Land tenure and rights' refers to an institutional arrangement that is used to manage the relationship between individuals or groups of people and the land either legally or customarily defined.

\section{Open-ended questions}

Unstructured questions in which possible answers are not suggested; the respondent gives a long answer in his or her own words.

\section{Partially open questions}

Similar to open-ended questions, but some answers are pre-categorised to facilitate recording and analysis.

\section{Study of livelihoods, land tenure and rights}

In simple terms, the 'study of livelihoods, tenure and rights' is about learning how livelihoods have been shaped by land tenure and rights and how the community conducts resource management in the area.

\section{Tenure security}

'Tenure security' is the certainty that a person's right to a certain area of land will be recognised by others and protected in the case of specific challenges. People with insecure tenure face the risk of their right to land being threatened by competing claims, or even lost following eviction. 


\section{Note 2 - Sampling techniques}

\section{Determining a sample size}

The appropriate sample size ultimately depends on the purpose of the study. For example, a population census will require $100 \%$ participation, and hence the sample size must equal $100 \%$. Factors such as the available resources (time, budget, human) will affect the sample size but care should be taken not to jeopardise the statistical relevance of the sample.

To determine the survey sample size, a simple percentage approach can be used, for example to interview $5 \%$ of the total number of households. Alternatively, a fixed minimum number of respondents can be used as the basis of the sample size.

For CoLUPSIA, the sample size was determined using a simple percentage approach (e.g. $5 \%$ of the total number of households) or using a fixed number of respondents approach (30 households) in each village. This resulted in 566 and 800 households in Central Maluku and Kapuas Hulu, respectively, being surveyed. This represents more than $5 \%$ of the total households or above the acceptable minimum number.

\section{Determining a random sample}

To determine the size of the sample to be surveyed using a random sample approach, take the following steps.

1. Identify and list the entire population of the village (e.g. with the name of the household head, village X) and number these 1-250.

2. Determine the desired sample size (e.g. 50 households).

3. Use whisk social gathering or generate random numbers from a computer to select the 50 households.

4. List the remaining households (e.g. 200 households), and then create a second list as Plan B, in case any of the originally selected households are unavailable or unwilling to participate.

Following are some tools for random sampling.

1. Whisk social gathering. This is the most convenient method, and materials are available in the field. Write down, on individual pieces of paper, the number of each household or representative group. Place the pieces of paper in a container, shake it and then pick out the required number at random. 





2. Calculator. If possible, bring a scientific calculator equipped with a random number generation function and take the following steps to generate random numbers.

a. Specify the total population size (e.g. 50 households).

b. To get a random number between 0 and 50, press the random function on the calculator and multiply by 50 ; that is, press 'ran\#' then * 50 .

c. The random number appears as a decimal; whole numbers can be obtained by rounding or by removing the decimal number (trunc) (e.g. 12.6342: round $=13$; trunc $=12$ ).

d. Repeat steps $2 \mathrm{~b}$ and $2 \mathrm{c}$ until the number (n) of the sample is drawn.

3. Computer program. If available, random numbers can be generated in the Microsoft Excel program, as follows.

a. Type the general formula for random numbers: $\operatorname{rand}()$

b. Repeat steps $2 \mathrm{a}, 2 \mathrm{~b}$ and $2 \mathrm{c}$. If using rounding to derive whole numbers, the formula is $=\operatorname{round}\left(50^{*} \operatorname{rand}(), 0\right)$. If removing the digits after the decimal, the formula is $=\operatorname{trunc}(50 * \operatorname{rand}())$.

Please note that the function 'rand()' is very sensitive in Excel: every time the cursor is moved, the random numbers will change. After the random numbers are generated, the list of random numbers generated serves as the first list. To copy the list without changing the value of the random numbers generated, use the command Copy ${ }^{\oplus}$ Paste Special ${ }^{\circledR}$ Values. 


\section{Note 3 - Choosing the most appropriate type of question format}

When designing a survey and conducting an interview, it is important to consider how a question can be structured, that is, whether it should be open or closed, or a mixture of both. The type of question and way that it is asked will affect the answer provided.

In general, questions can be either open or closed. The main difference between these two types of question is that open questions allow respondents to explain their answers, whereas closed questions do not.

With closed questions, respondents do not have the freedom to give an answer other than those provided in the list of questions. Partially open questions can also be used when conducting socio-economic surveys.

A survey/questionnaire will use a range of question types to ensure that the information is obtained in the most appropriate manner.

\section{Open questions}

\section{Open questions - example}

What is your opinion about the paddy rice harvest this year? Why has it declined?

Open questions provide no options for possible prompts or answers and the respondent is able to answer completely freely.

What can we learn from this type of question? Open-ended questions have both advantages and disadvantages, as detailed in Table 1. 
Table 1. Advantages and disadvantages of open questions

\begin{tabular}{ll}
\hline Advantages & Disadvantages \\
\hline $\begin{array}{l}\text { The interviewer can elicit more } \\
\text { information and possibly uncover } \\
\text { new information that had not been } \\
\text { previously considered. }\end{array}$ & $\begin{array}{l}\text { - The interviewer needs experience to } \\
\text { build discussion of particular topics } \\
\text { and record the findings. }\end{array}$ \\
$\begin{array}{l}\text { The interview records can be used in } \\
\text { the report as interesting illustrations. }\end{array}$ & - Data analysis requires expertise and a \\
lot of time. \\
$\begin{array}{l}\text { The responses provide additional } \\
\text { scope for analysis and allow a new } \\
\text { interpretation of the conclusions. }\end{array}$
\end{tabular}

To mitigate the disadvantages of open questions, those conducting the survey or interview can:

- Train interviewers and provide direction for ongoing tasks to improve the quality of the data collected.

- Prepare a list of questions that allow interviewers to systematically explore the respondents' answers.

- Use open questions in training sessions with the team members.

\section{Partially open questions}

\section{Partially open question - example:}

Over the past 5 (five) years, the amount of forest products consumed by households has:

a. increased, because......

b. decreased, because.......

In a partially open question, the answer is available as part of s category. Hence, the respondent is given a choice of responses: in the example above, the response is either 'increased' or 'decreased' (closed), but the respondent is given the opportunity to explain his or her answer provided using 'because ...' (open).

This type of question also has advantages and disadvantages, as set out in Table 2. 
Table 2. Advantages and disadvantages of partially open questions

\begin{tabular}{ll}
\hline Advantages & Disadvantages \\
\hline - Easy answers and quick note-taking & - Important answers could be missed \\
- Easy analysis & if there is no appropriate category \\
& provided. \\
& - Some information may be forced \\
& into existing categories and other \\
& information might be lost. \\
- If respondents hesitate and the & interviewer helps with grid answers, \\
& the results are potentially biased. \\
\hline
\end{tabular}

To mitigate the disadvantages of partially open questions, those conducting the survey or interview can:

- Record all answers by taking notes or using a voice recorder.

- If respondents do not give an answer, repeat the question in a different way but without leading the respondent to an answer.

\section{Closed questions}

\section{Closed questions - example:}

How often does MrX/Mrs Y experience the following problems or constraints in conducting agricultural business activities?

\begin{tabular}{llll}
\hline Wild pig attack & Often & Sometimes & Rarely \\
Attacks by other animals & Often & Sometimes & Rarely \\
Lack of capital & Often & Sometimes & Rarely \\
\hline
\end{tabular}

With closed questions, respondents must choose one of the available answers, and no room is provided for further explanation or elaboration. Using closed questions is useful when time is short and very specific information is required.

Again, this type of question has advantages and disadvantages, as detailed in Table 3. 
Table 3. Advantages and disadvantages of closed questions

Advantages Disadvantages

- Answers can be quickly gathered, thus saving time.

- Comparison of respondents' and groups' answers over time is easy.

- Further analysis of closed questions can be difficult because of the lack of supplementary questions for respondents to elaborate on the reasons for their answer.

To avoid the disadvantages of this type of question, the interviewer could ask further questions to explore respondents' answers in more depth. 


\section{Note 4 - Conducting the survey}

Before undertaking a survey, the following key steps should be followed.

1. Thorough preparation and scheduling of the survey work is essential for a successful survey. The survey team should be prepared and the work plan and timeframe for completing the surveys should be agreed with the team in advance. The roles and responsibilities of each team member should be clearly defined. Data sheets and questionnaires must be prepared and the team trained.



2. Ask permission from the village head prior to carrying out any survey. Ensure that the village has been informed and permission from the village head has been obtained sufficiently in advance of the survey.

3. If possible, a meeting with the community or at least the head of the village should take place at the start of the survey, to introduce the survey team members, to fully explain the survey, its purpose and how it will be conducted, 




and to allow for points of clarification and discussion with the community or village head. Meeting with the community requires organisation and planning, but it is an important part of starting any survey work. The team may need to work with the community leaders to ensure that villagers participate.

4. Ensure all team members are briefed and trained. Aim to ensure that there will be no changes in the trained survey team during the course of the survey work. This will help to ensure that data of consistent quality are gathered. Training should cover the approach to the survey (e.g. listening, asking openended questions) and interviewing skills, and should thoroughly cover the purpose of the survey and meaning of each question.

5. Avoid raising expectations of survey participants by clearly explaining the work and its possible results and outcomes. This is extremely important. 


\section{Note 5 - Guidance for community meetings}

Community meetings are vital to the success of surveys and it is important to engage communities in all aspects of land use planning. Building community engagement takes time and should not be forced or rushed. Socio-economic surveys and focus group discussions, if done correctly, can be a good way to begin building a relationship with the community. Often information collected during socio-economic surveys is personal in nature and even confidential, and it should always be handled sensitively.

The guidance below will help to ensure that the community meeting gets off to the best possible start.

- Set the village hall as the meeting place, and schedule the meeting with village leaders.

- Start the meeting by introducing all the team members, and then explain the purpose and background of the study and the role of the organisation undertaking the survey work. Ensure that the outputs of the survey work are clearly explained and expectations are realistic; that is, it is clear what the survey team and the organisation/project can and cannot deliver. Avoid making promises (see Box 1).

- Describe the activities and what will be achieved from this study. What will be provided to the community? How can the community participate? How can the community assist and advise the team during the study?

- Explain the importance of the study's schedule and activities and check whether there are potential problems or conflicts with local activities. Determine an acceptable schedule for major activities.

- Invite the villagers to introduce themselves or their village. Background information about the village is important and can be obtained during the community meeting (e.g. the total number of households, ethnicity, major activities of most villagers, etc.) Find out if villagers have time to participate in the survey as needed, and when they have time to do it.

- Informal discussions may guide the survey team to recognise key informants, especially those who have knowledge related to the study.

- Check whether any community members feel unhappy about the proposed activities. If so, explain any specific aspects that they find unacceptable. Be willing to accept specific bans and modify the approach accordingly.

- Close the meeting. Start planning survey activities based on the available options. 


\section{Box 1. An example of a briefing note used to introduce the survey team to a village}

Our purpose in visiting this village is to conduct activities that are related to the socio-economic conditions of the community. The activities include interviews and group discussions.

We understand that time is important for the community. Therefore, we will discuss the schedule of activities during our stay with the head of the village, based on the most convenient times for the community. Activities can be conducted in the morning, afternoon or night, depending on respondents' availability.

The information provided by the community is confidential, and we will not give this information to any other parties who might have different interests. Note also that the project is not related to the tax authorities. This project will not provide any direct cash benefits to the community. Furthermore, this project cannot make any promises about any activities to take place in this village in the future. However, we believe that the results from this study will benefit the community in the future, particularly by increasing the ability to discuss land use planning with local government. 


\section{Note 6 - Interview techniques}

Interviews can be done individually or in small groups of two or three people.

Before conducting the interview, the interviewer should prepare questions or know and understand the questionnaires to be used, and consider how the interview will be conducted.

- Clothes show who you are. Dressing in a polite, unobtrusive way, in accordance with local culture, will improve the level of acceptance by villagers.

- Be open. The interview process is not just 'to obtain data'; it is also 'to gain an understanding'. This requires an open mind and a good relationship with the community.

- Do not be influenced by pre-existing opinions. This is very important.

- Respondents' answers sometimes may sound unusual or be unexpected. Keep asking questions and seeking explanations to ensure that you fully understand the answer.

- In some communities, women are not familiar with being interviewed or are not free to meet with visitors or strangers. Find out whether they prefer to be interviewed by men or women, and the composition of the interview team can be structured accordingly. Be sensitive to gender issues. Ensure that the interview approach is consistent with social norms.

- The ability to listen and to recognise that the information provided by respondents is interesting is a skill and takes practice. Do not rush, and make respondents feel comfortable without feeling threatened by the questions.

- If respondents enthusiastically explain one particular topic that is not relevant to the survey subject, politely return them to the topic at hand.

Following the tips in Box 2 will help the interview process run more smoothly. 


\section{Box 2. Interview guide}

- Meet with villagers and try to establish a relationship that makes them feel comfortable and relaxed. Pay attention to posture and body language.

- Describe the purpose and objectives of the survey and explain the rules on confidentiality.

- Establish ground rules. Explain that it is fine if they do not know the answer.

- Keep it short, check the time and, if a respondent becomes restless, change the subject. If they stop paying attention, stop or take a break if needed. Do not rush; be patient and calm, but serious.

- Use simple language. Be prepared to find alternative ways to ask the same question.

- Do not give direction to informants or suggest your own opinion as an answer. Be patient and give the respondents time to think.

- Respect the various views, regulations and traditional culture (e.g. a man may not be able to interview female respondents on his own).

- Drop a sensitive issue or put it aside for a second interview. Do not force the informant to answer.

- Let the respondent talk, and even slightly deviate from the question, but not for too long.

- Provide teaching aids, maps or drawings to help you explain an idea.

- Certain activities, such as making a map, can help keep the community's interest.

- Greet respondents with a friendly smile.

- If appropriate, offer some compensation for missed work, but do not buy the information.

- Do not make any promises.

- Make sure to thank the informant. Advise them that you may need to come back to check information. 


\section{Note 7 - Focus group discussions}

A focus group discussion (FGD) aims to gather in-depth information on the concepts, perceptions and ideas of a group of 6-12 people. Ideally, an FGD is more than just a question-and-answer interaction. The implementation of an FGD is an iterative process, whereby each discussion builds on previous discussions by developing a topic or emphasis on certain aspects. This exercise requires a facilitator to guide the group members to discuss the required topics. It is beneficial if other research instruments such as key informant interviews, in-depth interviews or other qualitative techniques are used in conjunction with FGDs.

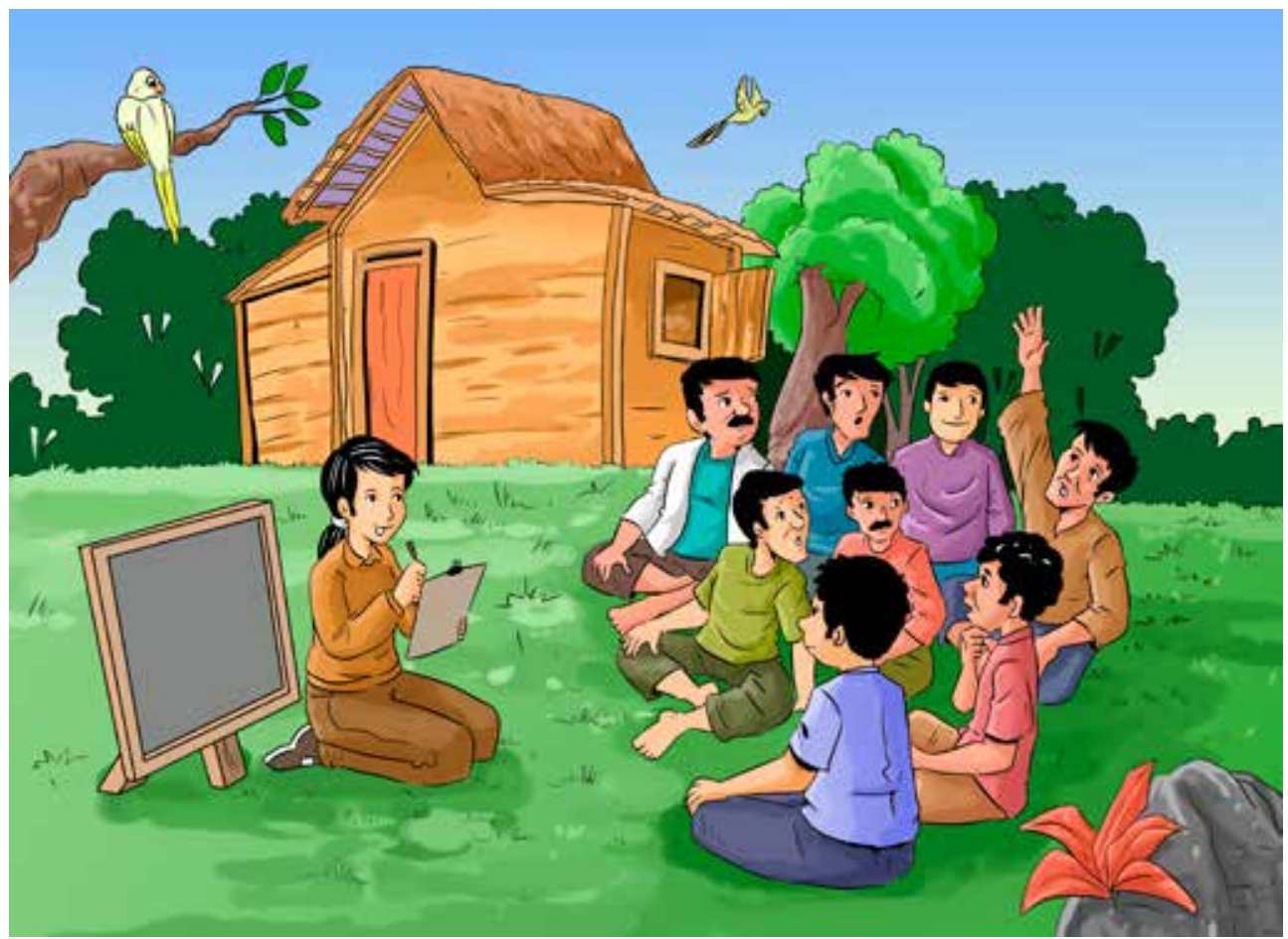

In the context of a collaborative land use planning project involving local communities in a forested area, an FGD could include discussions on institutional arrangements, community rights, community access to forest, the use of forest by the community and sustainable management of forest resources. Examples of aspects that could be discussed during the FGD exercise are given below (Table 4). 
Table 4. Examples of themes and topics for discussion in FGDs

\begin{tabular}{ll}
\hline Themes & Topics \\
\hline Identification of stakeholders & $\begin{array}{l}\text { The situation of the parties concerned, the activities } \\
\text { carried out and the potential impacts }\end{array}$ \\
Rights to forest resources & $\begin{array}{l}\text { An understanding of the rights to forest resources } \\
\text { The pattern of forest resource use, distribution } \\
\text { of profits }\end{array}$ \\
Forest management, & $\begin{array}{l}\text { Stock of natural resources } \\
\text { enforcement and compliance }\end{array}$ \\
& $\begin{array}{l}\text { The function of forest management } \\
\text { Forest management rules, enforcement and sanctions } \\
\text { Decision-making } \\
\text { Pillage development projects }\end{array}$ \\
\hline
\end{tabular}

Before conducting an FGD, team members must analyse the situation, recruit participants and arrange sessions.

1. Analyse the situation to ascertain good knowledge of the local conditions, to ensure discussions take account of local issues and demographic and social conditions. This will also help to make the FGD targeted.

2. Recruit participants so that a wide range of backgrounds is represented in the group. The groups should be divided based on age and gender. All those involved should be assured of the confidentiality of all responses provided. Participants should be given at least one day's notice of the meeting to ensure maximum participation. Explain to participants why it is important to have diversity in the group, that is, to ensure that different opinions are expressed.

3. Make arrangements prior to the discussion. Effective communication and interaction will lead to high-quality results from the FGD. Preparation is therefore essential. This includes choosing the location and setting it up carefully, for example, arrange chairs in a circle and not classroom format, avoid distractions and make sure the location is perceived as a neutral place by those participating. Be prepared, with a discussion paper holding a series of open questions.

4. During the discussion sessions, to ensure effective exchange of opinions, team members should divide the tasks (i.e. a facilitator (see Box 3), record/ note-taker). 

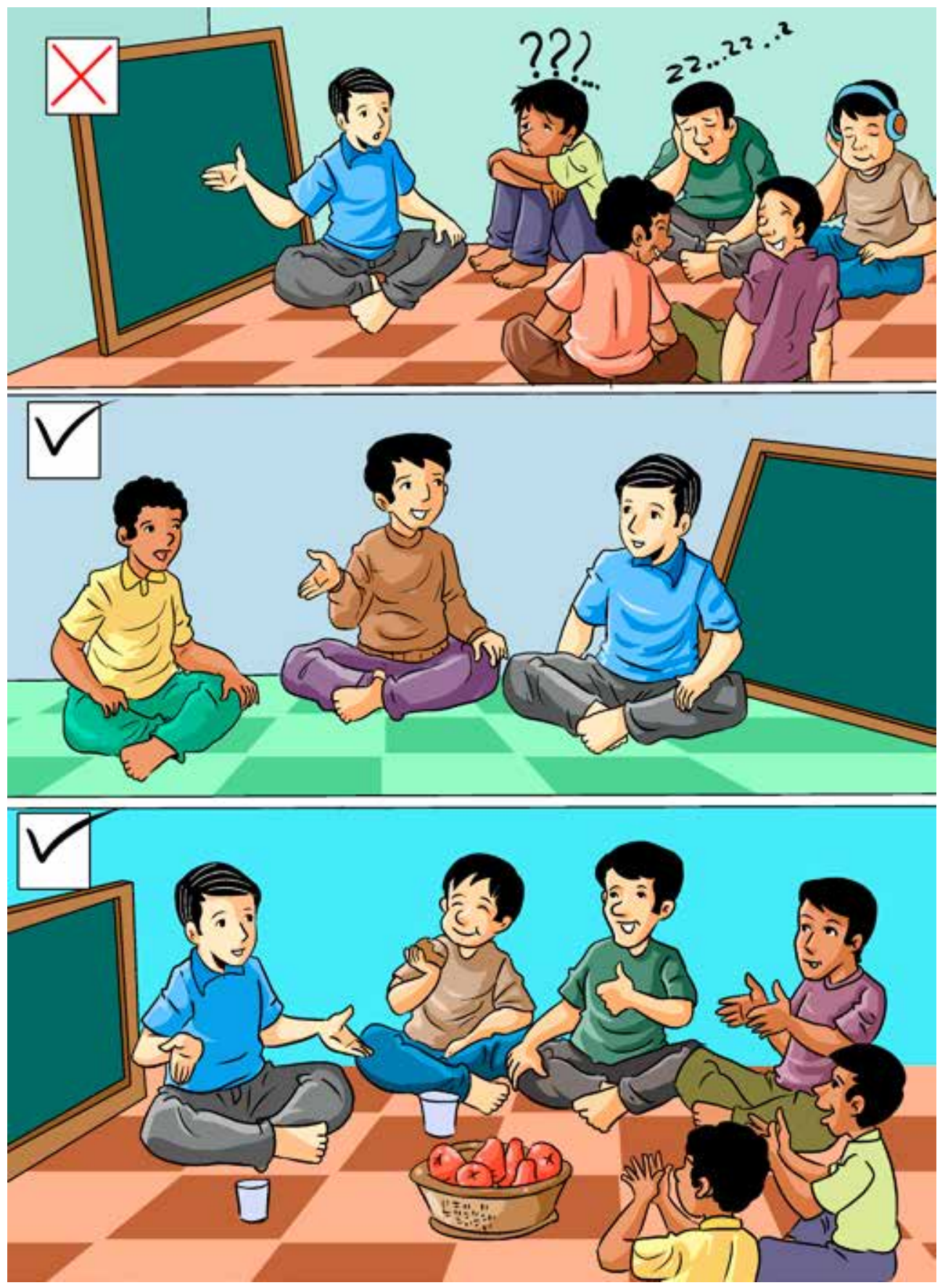


\section{Box 3. The role of facilitator}

- The facilitator should NOT act as an expert on the topic. The facilitator's role is to stimulate and to provide direction during the discussion.

- As the facilitator, introduce yourself and the team members involved. Ask participants to introduce themselves with whatever name they want to use.

- Explain clearly the purpose of the FGD, the information needed and how the information will be used. Ask permission to use the voice recorder and reiterate the rules of confidentiality.

- Establish discussion rules agreed by all the participants, e.g. smoking rules.

- Show interest in the ideas of the group, make eye contact with participants and use humour if necessary but only if appropriate. Use questions that encourage participants to express their views as much as possible. Remember that there is no right or wrong answer. React in a neutral and fair way to both verbal and non-verbal responses.

- Build rapport and empathy, and avoid being placed in the role of expert.

- Do not feel that the facilitator must say something during pauses in the discussion. Wait and see what happens. Keep the rhythm of the discussion. Remember that the role of the facilitator is to ensure all participants express their ideas.

- Listen carefully and shift the discussion from one topic to another slowly. If participants spontaneously switch to another topic, let the discussion run for a while, make a brief conclusion and go back to the original discussion topic.

- At the end of the meeting, do not forget to make any conclusions and to summarise the discussion. Ask participants if anything is missing from the conclusions. Thank them for their participation and time.

5. Ensure active engagement by all participants. It is important that team members work together to ensure that all participants are equally involved in the discussion. Use prompting questions to ensure active participation. Split the group to accommodate contrasting views and backgrounds, if this will generate more discussion. The facilitator should, if required, question the group to get responses.

6. Writing up the key discussion process and points after the FGD is important. This should highlight key topics discussed; topics that were perhaps difficult to discuss; the degree of consensus in the group; findings that were unexpected; and if there are any changes recommended for future FGD. 
7. Record all the information. The entire discussion and all points raised should be recorded, because the process is based on open or guiding questions, to ensure nothing is missed or points taken out of context. Note-taking should be shared and, if possible, supplemented with a recording, using the appropriate media tool, such as a voice recorder or something similar.

8. Number the session and its duration. The duration can vary depending on the dynamics of the participants, but ideally an FGD takes between 60 and 90 minutes. The first session may take a little longer when people are new to the process. 


\section{Note 8 - Example questionnaire templates: Household, village and key informant}

Questionnaire 1. Village profile - Key informant (e.g. village head, etc.)

\begin{tabular}{|c|c|}
\hline Province & : \\
\hline District & : ................................ \\
\hline Subdistrict & \\
\hline Village & $: \ldots$ \\
\hline Date & : \\
\hline Interviewer & 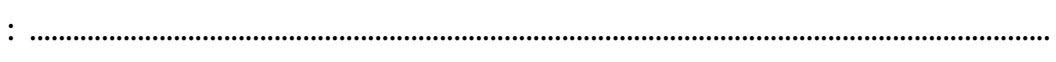 \\
\hline Note-taker & $:$ \\
\hline
\end{tabular}

\section{Key informant}

1 Name :

2 Age

3 Position :

4 How long have you been serving in this village?

5 Does the position of village head tend to be hereditary? $\square$ Yes $\square$ No

\section{A. Village}

A.1 Village description

A.1.1 Type of village:

$\square$ Old $\square$ Transmigration $\square$ New $\square$ Other

A.1.2 Does the community still practise and apply customary law?

$\square$ Yes $\square$ No

A.1.3 What is the name of the customary (adat) leader?

A.1.4 When was the village established?

According to village history, when did the settlement begin?

A.2 Dusun/Kampong

A.2.1 How many dusun/kampong are in this village? ......... dusun/kampong

A.2.2 Please name them 
A.2.3 Which dusun/kampong are located near the forest?

\begin{tabular}{llll}
\hline Name & $\begin{array}{l}\text { Forest status. KOD } \\
\text { (see Table A.2.4) }\end{array}$ & $\begin{array}{l}\text { Year of } \\
\text { establishment }\end{array}$ & $\begin{array}{l}\text { Distance from } \\
\text { settlement to } \\
\text { the forest (km) }\end{array}$
\end{tabular}

A.2.4 Land and forest status (KOD)
A. Ownership/Control over forestland
B. Use
By law:
1. Used by the state
1. State forest
2. Communal use
2. Private forest
3. Used by individuals
3. Customary forest
4. Used without permission
4. Private property
5. Used with permission (borrowing)
5. Right of exploitation (HGU), right to build (HGB) and forest concession (HPH)
By customs/tradition:
1. Customary forest
2. Private land

\section{A.3 Village boundary}

A.3.1 Village area? (approximate) ........... ha

A.3.2 How clear is the boundary with the neighbouring village?

\section{Clear $\square$ Not very clear}

A.3.3 What kinds of administrative boundary (1) and natural boundary

(2) are in place for the village? How far is the boundary from the village centre?

\begin{tabular}{cllllll}
\hline Direction & \multicolumn{2}{l}{ Administrative boundary } & $\begin{array}{l}\text { Natural/physical } \\
\text { boundary }\end{array}$ & \multicolumn{2}{l}{ Condition } \\
\cline { 2 - 6 } & $\begin{array}{l}\text { Neighbouring } \\
\text { village }\end{array}$ & $\begin{array}{l}\text { Distance } \\
(\mathbf{k m})\end{array}$ & Landmark & $\begin{array}{l}\text { Distance } \\
(\mathbf{k m})\end{array}$ & Clear & Not clear \\
\hline
\end{tabular}

North

South

West

East

A.3.4 Do any villagers conduct their agricultural/animal husbandry activities outside the village boundary? $\square$ Yes $\square$ No 
A.3.5 Where do they carry out such activities? (see the land and forest status, KOD)

A.4 Village environment

A.4.1 Community forest: community forest (private forest), owned by community (private landowner), outside state forest area

A.4.1.1 Is there any community forest (private forest) that is used by your community? $\square$ Yes $\square$ No

A.4.1.2 What is the name of community forest (private forest)?

A.4.1.3 Please provide the following information about the forest.

\begin{tabular}{|c|c|c|c|c|c|}
\hline Name & Area & Direction $^{a}$ & Distance $^{b}$ & $\begin{array}{l}\text { Length } \\
\text { of tripc }\end{array}$ & $\begin{array}{l}\text { Forest status, } \\
\text { KOD }\end{array}$ \\
\hline
\end{tabular}

a Direction: 1 = north, 2 = south, 3 = west, $4=$ east

b Distance: $1=0-5 \mathrm{~km}, 2=5-10 \mathrm{~km}, 3=10-15 \mathrm{~km}, 4=$ more than $15 \mathrm{~km}$

c Length of trip on foot: $1=$ less than 1 hour, $2=1-2$ hours, $3=2-4$ hours, $4=$ more than half a day

Complete the KOD using the land status reference (Table A.2.4)

A.4.2 Customary forest (adat, petuanan, ulayat etc.): State forest managed by a customary community.

A.4.2.1 Is there any customary forest (private forest) that is used by your community? $\square$ Yes $\square$ No

A.4.2.2 What is the name of the customary forest?

A.4.2.3 Please provide the following information about the forest.

\begin{tabular}{|c|c|c|c|c|c|c|}
\hline Name & Area & Direction $^{\mathrm{a}}$ & Distance $^{b}$ & $\begin{array}{l}\text { Length } \\
\text { of tripc }\end{array}$ & $\begin{array}{l}\text { Forest } \\
\text { type }^{d}\end{array}$ & $\begin{array}{l}\text { Forest status, } \\
\text { KOD }\end{array}$ \\
\hline
\end{tabular}

a Direction: 1 = north, 2 = south, 3 = west, 4 = east

b Distance: $1=0-5 \mathrm{~km}, 2=5-10 \mathrm{~km}, 3=10-15 \mathrm{~km}, 4=$ more than $15 \mathrm{~km}$

C Length of trip on foot: $1=$ less than 1 hour, $2=1-2$ hours, $3=2-4$ hours, $4=$ more than half a day

d Forest type: 1 = conservation forest, 2 = protection forest, $3=$ production forest

Complete the KOD using the land status reference (Table A.2.4) 
A.4.3 Distance to protection forest

Protection forest is controlled by the state. People are allowed to use the forest except for cutting timber

A.4.3.1 Do you know where the protected forest is? $\square$ Yes $\square$ No

A.4.3.2 If yes, what is the name of the forest?

A.4.3.3 What direction is it from this village?

North $\square$ East $\square$ South $\square$ West

A.4.3.4 How far is the forest from this village? .......... km

A.4.3.5 If the villagers travel by foot to the forest boundary, how long does the trip take? $\square$ Less than one hour $\square$ 1-2 hours $\square$ 2-4 hours More than half a day

\begin{tabular}{|c|c|c|c|c|}
\hline Name of forest & $\begin{array}{l}\text { Category (national } \\
\text { park, protection forest, } \\
\text { natural reserve*) }\end{array}$ & Direction & $\begin{array}{l}\text { Distance } \\
(\mathbf{k m})^{\mathrm{a}}\end{array}$ & $\begin{array}{l}\text { Length of } \\
\text { trip (hours) }\end{array}$ \\
\hline
\end{tabular}

a Distance: $1=0-5 \mathrm{~km}, 2=5-10 \mathrm{~km}, 3=10-15 \mathrm{~km}, 4=$ more than $15 \mathrm{~km}$

b Length of trip on foot: $1=$ less than 1 hour, $2=1-2$ hours, $3=2-4$ hours, $4=$ more than half a day

* select as appropriate

\section{A.4.4 Companies}

A.4.4.1 Is your village near any private companies? Name of company(ies)

Yes (Go to A.4.4.2) $\square$ Not yet (Go to A.4.4.2)

No (Go to section $B)$

A.4.4.2 Do you know the location of the boundary between the village and the company? $\square$ Yes $\square$ No

A.4.4.3 What direction is it from this village?

North $\square$ East $\square$ South $\square$ West

A.4.4.4 How many kilometres from the village is the company's boundary?

A.4.4.5 If the villagers travel by foot to the company's boundary, how long does the trip take? $\square$ Less than one hour $\square 1-2$ hours $\square$ 2-4 hours

More than half a day 
A.4.4.6 What area does the company cover? What are its activities?

\begin{tabular}{lllllll}
\hline $\begin{array}{l}\text { Name of } \\
\text { company }\end{array}$ & Area Direction $^{\mathrm{a}}$ & $\begin{array}{l}\text { Distance } \\
(\mathbf{k m})\end{array}$ & $\begin{array}{l}\text { Length } \\
\text { of trip }^{\mathrm{b}}\end{array}$ & $\begin{array}{l}\text { Type of } \\
\text { activity }^{\mathrm{c}}\end{array}$ & $\begin{array}{l}\text { Planned/ } \\
\text { Currently in } \\
\text { operation }\end{array}$ & $\begin{array}{l}\text { Forest } \\
\text { status, } \\
\text { KOD }\end{array}$
\end{tabular}

a Direction: $1=$ North, 2 = South, $3=$ West, 4 = East

b Length of trip on foot: $1=$ less than 1 hour, $2=1-2$ hours, $3=2-4$ hours, $4=$ more than half a day

C Type of activity: $1=$ forest concession $(\mathrm{HPH}), 2=$ oil palm, $3=$ rubber, $4=$ cocoa, $5=$ fish canning, $6=$ coconut, $7=$ forest plantation, $8=$ sawmill, $9=$ ranch, $10=$ other

Complete the KOD using the land status reference (Table A.2.4)

A.4.5 Border issues

A.4.5.1 Does the village have a clear border? $\square$ Yes $\square$ No

A.4.5.2 Has the village ever had any problems related to the boundary with neighbouring villages or the forest area? $\square$ Yes $\square$ No

A.4.5.3 If yes, please describe the border issue

B. Demography

B.1 Population

B.1.1 Number of households in the village this year? ........... households

B.1.2 Number of households in the village last year? ........... households

(Number of households this year minus newly married couples and outmigration)

B.1.3 Population of the village? people

B.1.4 Population of the village last year? people

\begin{tabular}{lllllll}
\hline & $\begin{array}{l}0-4 \\
\text { years old }\end{array}$ & $\begin{array}{l}5-14 \\
\text { years old }\end{array}$ & $\begin{array}{l}15-60 \\
\text { years old }\end{array}$ & $\begin{array}{l}>60 \\
\text { years old }\end{array}$ & $\begin{array}{l}\text { Total, } \\
\text { current year }\end{array}$ & $\begin{array}{l}\text { Total, } \\
\text { last year }\end{array}$ \\
\hline Households & $x x x x$ & $x x x$ & $x x x$ & $x x x x$ & & \\
Male & & & & & & \\
Female & & & & & & \\
Total & & & & & & \\
\hline
\end{tabular}


B.2 Ethnic composition

B.2.1 What ethnic groups make up this village?

B.2.1.1 What is the ethnic group of the original inhabitants of this village?

B.2.1.2 Are there outsiders (members of other ethnic groups) living in this village? Where did they come from? How many households do they account for?

\begin{tabular}{ll}
\hline Ethnic composition (including outsiders) & Number of households Number of people \\
\hline 1 \\
2 \\
3 \\
4 \\
5
\end{tabular}

B.2.2 What local language is spoken?

B.3 Religion composition

B.3.1 What religion(s) do the villagers practise?

B.3.2 How many religious facilities/places of worship are in this village?

\begin{tabular}{llll}
\hline Religion & Number of households & $\begin{array}{l}\text { Religious facility/ } \\
\text { Place of worship }\end{array}$ & Total \\
\hline Protestant Christian & & Protestant church \\
Catholic Christian & Catholic church \\
Muslim & Mosque \\
\hline Buddhist & Monastery \\
Hindu & Temple \\
\hline Other ............ & Other ............. \\
\hline
\end{tabular}
C. Infrastructure
C.1 Education
C.1.1 What types of schools are available for this village?
C.1.2 How many school buildings are in this village?
C.1.3 How many students are enrolled in the school this year? 
C.1.4 How many teachers work at this school? (including teachers residing outside the village)

\begin{tabular}{l} 
Type of school Number of pupils Number of teachers Number of buildings \\
\hline Kindergarten \\
Primary school \\
Junior high school \\
High school \\
University
\end{tabular}

C.1.5 Community education attainment

\begin{tabular}{ll}
\hline Education attainment & Total no. of people or\% of population \\
\hline Illiterate & \\
Elementary school - graduate or below & \\
\hline Junior high school - graduate & \\
High school - graduate & \\
Bachelor degree or above & \\
\hline
\end{tabular}

C.2 Housing

C.2.1 How many houses are in this village? ........... houses

C.2.2 Are there households that live not in the village but in the surrounding fields? $\square$ Yes $\square$ No

C.2.3 If yes, how many households are there? .......... households

C.2.4 How many houses were built last year? .......... houses

C.2.5 How much timber/sawnwood is needed to build one house? ......... $\mathrm{m}^{3}$

C.3 Health

C.3.1 Type of health facilities in the village:

Rural clinic $\square$ Rural health centre

$\square$ Subsidiary rural health centre $\square$ Village midwife's house

$\square$ Other

C.3.2 The number of medical personnel in this village: people

C.3.3 The most senior medical professional in this village:

$\square$ Registered health worker $\square$ Doctor $\square$ Nurse

$\square$ Village midwife $\square$ Other

C.3.4 How frequently does a doctor visit this village? times/ year-month-week*) 
C.3.5 The (two) most common illnesses are:

$1 /$

21

C.3.6 How many certified midwives are there?

certified midwives

C.3.7 How many traditional midwives are there? traditional midwives

C.3.8 Do people in this village use traditional medicines (medicinal plants, etc.)? $\square$ Yes $\square$ No

C.3.9 Where do they collect such plants from?

\begin{tabular}{l}
\hline Plant origin \\
\hline Home garden \\
Paddy field \\
Garden \\
Dry field \\
Forest \\
Thicket surrounding village \\
Other ............
\end{tabular}

C.4 Sanitation

C.4.1 Please describe sanitation and energy use in this village.

Source of energy Number of houses or\% of population Since when?

Fuelwood

Kerosene

Charcoal (coconut shells, etc.)

State company electricity

Diesel electricity

Source of water

Open well

Closed well (drilled, etc.)

River

\section{Latrine}

Water closet

C.5 Transport

C.5.1 Access to market

Where do the villagers sell their products? How many times a week? 
C.5.1.1 How far is the village from the nearest big market? ........... km

C.5.1.2 What is the name of the nearest market?

C.5.1.3 How many times a week is the market held? $\square$ Once $\square$ Twice Three times $\square$ More than three times $\square$ Everyday

C.5.1.4 Please provide the following information about travelling from the village to the nearest market.

\begin{tabular}{llll}
\hline Component & Road & River & Sea
\end{tabular}

Length of trip ${ }^{a}$

Transport cost/person

Transport cost/kilogram

Length of use?*

Frequency (per week)

Accessibility ${ }^{b}$

a Length of trip: $1=$ less than 1 hour, $2=1-2$ hours, $3=2-4$ hours, $4=$ more than 4 hours

b Accessibility: $1=$ good access, $2=$ accessible but difficult, $3=$ sometimes inaccessible (150-365 days passable), $4=$ inaccessible (fewer than 150 days passable)

* The length of time that the respondent has been using the stated type of transport (road/river/sea)

C.5.2 Access to subdistrict administration (kecamatan)

C.5.2.1 How far is the village from the subdistrict capital? ........... $\mathrm{km}$

C.5.2.2 What is the name of the subdistrict capital?

Component Road $\quad$ River

Length of trip ${ }^{\mathrm{a}}$

Transport cost/person

Transport cost/kilogram

Length of use?

Frequency (per week)

Accessibility $^{b}$

a Length of trip: $1=$ less than 1 hour, $2=1-2$ hours, $3=2-4$ hours, $4=$ more than 4 hours

b Accessibility: 1 = good access, 2 = accessible but difficult, $3=$ sometimes inaccessible

(150-365 days passable), $4=$ inaccessible (fewer than 150 days passable)

* The length of time that the respondent has been using the stated type of transport (road/river/sea) 

D. Village economy
D.1 Cooperative
D.1.1 Is there an active cooperative in this village? $\square$ Yes $\square$ No (Go to D.1.3)
D.1.2 What are the cooperative's activities?

\begin{tabular}{lll}
\hline Activity Community kiosk & $\begin{array}{l}\text { Savings } \\
\text { and loans }\end{array}$ & Agriculture kiosk Marketing Other ..... \\
\hline Yes $/ \mathrm{No}^{*}$ & & \\
\hline
\end{tabular}

D.1.3 Do people have access to credit? From what sources?

\begin{tabular}{|c|c|c|c|c|c|}
\hline Source of credit & Yes & No & Source of credit & Yes & No \\
\hline Bank & & & Government assistance & & \\
\hline Village cooperative & & & Social revolving fund (arisan) & & \\
\hline Village's petty cash & & & Other ................ & & \\
\hline Money lender & & & ............ & & \\
\hline
\end{tabular}

D.2 Agricultural production facilities

D.2.1 Do farmers use irrigation for farming? $\square$ Yes $\square$ No (Go to D.2.2)

Infrastructure Since when Area (ha) Number of households covered

Simple irrigation

Semi-technical irrigation

Technical irrigation

D.2.2 What are the most common agricultural products?

\begin{tabular}{lllll}
\hline Type of land use & \multicolumn{2}{c}{ Product 1} & Product 2 & \multicolumn{2}{c}{ Product 3} \\
\cline { 2 - 5 } & Name Ha $\quad$ Name Ha $\quad$ Name Ha \\
\hline Home garden & & & & \\
Dry field & & & \\
Paddy field & & & & \\
Plantation & & & & \\
\hline
\end{tabular}

D.2.3 How much area is planted with the main crops? 
D.2.3.1 Do farmers use superior seeds? $\square$ Yes $\square$ No

\begin{tabular}{|c|c|c|c|c|c|}
\hline \multirow[t]{2}{*}{ Commodity } & \multicolumn{2}{|c|}{ D.2.3: Main crops } & \multicolumn{3}{|c|}{ D.2.3.1: Superior seeds } \\
\hline & Area, total (ha) & Land status, KOD & Area* & Since & $\begin{array}{l}\text { Number of } \\
\text { households }\end{array}$ \\
\hline \multicolumn{6}{|l|}{ Maize } \\
\hline \multicolumn{6}{|l|}{ Paddy } \\
\hline \multicolumn{6}{|l|}{ Rubber } \\
\hline Coconut & & & & & \\
\hline
\end{tabular}

Complete the KOD using the land status reference (Table A.2.4)

D.2.3.2 Do farmers use fertilizer/pesticide/herbicide/fungicide?

$\square$ Yes (fill in the table) $\square$ No

\begin{tabular}{lllllllllll}
\hline Commodity & Fertilizer & \multicolumn{2}{l}{ Pesticide } & \multicolumn{2}{l}{ Herbicide } & \multicolumn{2}{l}{ Fungicide } \\
\cline { 2 - 10 } & Area Since & HH & Area Since & HH & Area Since & HH & Area & Since & HH \\
& (ha) & & (ha) & & (ha) & & (ha) & \\
\hline
\end{tabular}

Maize

Paddy

Rubber

Coconut

Note: $\mathrm{HH}=$ households (no. of)

D.2.4 Assets

D.2.4.1 How many chainsaws are used in the village? .......... units

D.2.4.2 How many households own a chainsaw? ........... households

D.2.4.3 Please describe the assets held by villagers.

Total Number of households that own the asset

Car/truck

Motorcycle

TV

Satellite receiver

$\mathrm{CD} / \mathrm{VCD} / \mathrm{DVD}$ player

Mobile phone/telephone 
D.2.4.3 Continued

\begin{tabular}{|c|c|c|c|}
\hline \multicolumn{4}{|c|}{ Number of households that own the asset } \\
\hline \multicolumn{4}{|l|}{ Radio } \\
\hline \multicolumn{4}{|c|}{ Outboard motor } \\
\hline \multicolumn{4}{|c|}{ Refrigerator } \\
\hline \multicolumn{4}{|c|}{ …................... } \\
\hline D.2.5 & \multicolumn{3}{|l|}{ Cost of doing agriculture } \\
\hline D.2.5.1 & Land prices (per ha) & & \\
\hline \multirow{2}{*}{\multicolumn{2}{|c|}{ Type of land }} & \multicolumn{2}{|c|}{ Purchase price } \\
\hline & & Planted land & Bare land Planted land \\
\hline \multicolumn{4}{|c|}{ Dry land near the village } \\
\hline \multicolumn{4}{|c|}{ Dry land far from the village } \\
\hline \multicolumn{4}{|c|}{ Newly cleared land } \\
\hline Paddy fis & & & \\
\hline
\end{tabular}

D.2.5.2 Labour costs (daily wage)

\begin{tabular}{lllllll}
\hline Type of land & \multicolumn{2}{l}{ Ploughing/Planting } & \multicolumn{2}{l}{$\begin{array}{l}\text { Maintenance/ } \\
\text { Weeding }\end{array}$} & \multicolumn{2}{l}{ Harvesting } \\
\cline { 2 - 7 } & Male & Female & Male & Female & Male & Female \\
\hline Dry field & & & & & & \\
Paddy field & & & & & & \\
\hline Garden/Plantation & & & & & & \\
\hline
\end{tabular}

D.2.5.3 Cost of clearing new land (per ha)

D.2.5.3.1 How much land do farmers clear for agriculture each year? .......... ha

D.2.5.3.2 How much does it cost to clear fallow land or forest for agriculture?

\begin{tabular}{|c|c|c|c|c|}
\hline \multirow[t]{2}{*}{ Component } & \multicolumn{2}{|l|}{ Fallow land } & \multicolumn{2}{|l|}{ Forest } \\
\hline & Person days & Daily wage & Person days & Daily wage \\
\hline \multicolumn{5}{|l|}{$\begin{array}{l}\text { Felling the trees (including } \\
\text { renting a chainsaw) }\end{array}$} \\
\hline \multicolumn{5}{|l|}{$\begin{array}{l}\text { Cutting/splitting/sawing } \\
\text { the timber }\end{array}$} \\
\hline \multicolumn{5}{|l|}{ Transporting the wood } \\
\hline \multicolumn{5}{|l|}{ Preparing the land } \\
\hline Burning off & & & & \\
\hline
\end{tabular}


D.2.5.4 Who in the village decides whether to clear new land?

Own family $\square$ Village head $\square$ Collective within community

Other

D.2.6 What are the main agricultural products in this village?

\begin{tabular}{|c|c|c|c|c|c|c|c|c|c|c|}
\hline \multirow{3}{*}{$\begin{array}{l}\text { Agricultural } \\
\text { products }\end{array}$} & \multicolumn{8}{|c|}{ Marketed products } & \multirow{3}{*}{$\begin{array}{l}\text { Form in } \\
\text { which it } \\
\text { is sold } \\
\text { (wet/dry) }\end{array}$} & \multirow{3}{*}{$\begin{array}{l}\text { Direct } \\
\text { sales } \\
\text { to the } \\
\text { buyer/to } \\
\text { market }\end{array}$} \\
\hline & \multirow[b]{2}{*}{ Unit * } & \multirow[b]{2}{*}{$\begin{array}{l}\text { Quantity } \\
\text { produced }\end{array}$} & \multirow[t]{2}{*}{ Gross } & \multicolumn{2}{|c|}{ Price/kg } & \multirow[t]{2}{*}{ Net } & \multicolumn{2}{|c|}{ Price/kg } & & \\
\hline & & & & $\begin{array}{l}\text { This } \\
\text { year }\end{array}$ & $\begin{array}{l}\text { Last } \\
\text { year }\end{array}$ & & $\begin{array}{l}\text { This } \\
\text { year }\end{array}$ & $\begin{array}{l}\text { Last } \\
\text { year }\end{array}$ & & \\
\hline Paddy & & & $\begin{array}{l}\text { Unhulled } \\
\text { rice }\end{array}$ & & & Rice & & & & \\
\hline
\end{tabular}

Notes: * if using the local unit of measurement, convert to $\mathrm{kg}$

D.2.7 Farmers group

D.2.7.1 Have the farmers established a farmers group?

$\square$ Yes $\square$ No (Go to D.3.)

D.2.7.2 What crops does the group grow? (fill in the table)

D.2.7.3 Is the group formal or informal? $\square$ formal $\square$ informal

D.2.7.4 How many male members?

D.2.7.5 How many female members? (fill in the table)

\begin{tabular}{|c|c|c|c|}
\hline me of group & Crops grown & $\begin{array}{l}\text { Status } \\
\text { (formal/informal) }\end{array}$ & Male members \\
\hline
\end{tabular}

D.3 Livestock and fisheries

D.3.1 What livestock are raised in the village?

\begin{tabular}{|c|c|c|c|}
\hline Livestock & Total & Number of households & Husbandry system \\
\hline \multicolumn{4}{|l|}{ Buffalos } \\
\hline \multicolumn{4}{|l|}{ Cattle } \\
\hline \multicolumn{4}{|l|}{ Horses } \\
\hline Pigs & & & \\
\hline
\end{tabular}


D.3.1 Continued

\begin{tabular}{lll}
\hline Livestock & Total & Number of households \\
\hline Sheep/goats & & \\
Ducks & \\
Chickens & \\
Other &
\end{tabular}

a $1=$ wild, $2=$ tethered, $3=$ stabled at night, $4=$ grazing, $5=$ permanently stabled

D.3.2 Price of livestock

\begin{tabular}{|c|c|c|c|c|c|c|}
\hline \multicolumn{6}{|c|}{ Price/animal } & \multirow{2}{*}{$\begin{array}{l}\text { Price/ } \\
\text { animal }\end{array}$} \\
\hline \multirow[t]{4}{*}{ Buffalos } & \multirow[t]{2}{*}{ Male } & Mature & \multirow[t]{4}{*}{ Pigs } & \multirow[t]{2}{*}{ Male } & Mature & \\
\hline & & Calf & & & Piglet & \\
\hline & \multirow[t]{2}{*}{ Female } & Mature & & \multirow[t]{2}{*}{ Female } & Mature & \\
\hline & & Calf & & & Piglet & \\
\hline \multirow[t]{4}{*}{ Cattle } & \multirow[t]{2}{*}{ Male } & Mature & & & & \\
\hline & & Calf & & & & \\
\hline & \multirow[t]{2}{*}{ Female } & Mature & & & & \\
\hline & & Calf & & & & \\
\hline \multirow[t]{4}{*}{ Goats } & \multirow[t]{2}{*}{ Male } & Mature & Ducks & & & \\
\hline & & Lamb & Chickens & & & \\
\hline & \multirow[t]{2}{*}{ Female } & Mature & ….................. & & & \\
\hline & & Lamb & ...................... & & & \\
\hline
\end{tabular}

D.3.3 Fisheries (freshwater, sea, etc.)

\begin{tabular}{lllll}
\hline Fish gear & Fisher status $^{\mathrm{a}}$ & $\begin{array}{l}\text { Number of } \\
\text { households }\end{array}$ & & $\begin{array}{l}\text { Fish catch/ } \\
\text { products }^{\mathrm{b}}\end{array}$ \\
\hline Fish cage & & \\
Gill net & & \\
Net & & \\
Fish trap & & \\
& & \\
\end{tabular}

a Status: $1=$ whole year, 2 = seasonal, $3=$ cultivation

b E.g. arowana, toman etc. 
D.4 Economic activities

D.4.1 List the most common activities

\begin{tabular}{|c|c|c|c|}
\hline \multirow{2}{*}{\multicolumn{4}{|c|}{ Number of households }} \\
\hline & & & \\
\hline \multicolumn{4}{|c|}{2} \\
\hline \multicolumn{4}{|l|}{3} \\
\hline \multicolumn{4}{|l|}{4} \\
\hline \multicolumn{4}{|l|}{5} \\
\hline \multicolumn{4}{|l|}{6} \\
\hline \multicolumn{4}{|l|}{7} \\
\hline 8 & & & \\
\hline
\end{tabular}

a Status: $1=$ permanent for whole year, $2=$ seasonal, $3=$ unfixed in the year, $4=$ unfixed between years

D.4.2. Gathering of forest products

\begin{tabular}{llll}
\hline No Activities & Status $^{\mathrm{a}}$ & $\begin{array}{l}\text { Number of Price/unit } \\
\text { households }\end{array}$ & $\begin{array}{l}\text { Forest status, } \\
\text { KOD }\end{array}$ \\
\hline 1 & & & \\
2 & & \\
3 & & \\
4 & & \\
5 & & \\
6 & & \\
7 & & \\
8 & & \\
\hline
\end{tabular}

a Status: $1=$ permanent for whole year, $2=$ seasonal, $3=$ unfixed in the year, $4=$ unfixed between years

Complete the KOD using the land status reference (Table A.2.4)

D.4.2.1 How much fuel wood does a family use (two adults, two children) in a month?

D.4.2.2 How much wood is used to build a standard house (occupied by two adults, two children)? $\mathrm{m}^{3}$ 
D.5 Land use distribution

\begin{tabular}{llll}
\hline Area (ha) & \multicolumn{2}{l}{ Number of households } & \\
\cline { 2 - 4 } & Dry field Paddy field Garden & Garden & Garden \\
& & & \\
Landless & & \\
$<1$ ha & & \\
$1-1.9$ ha & & \\
$2-4.9$ ha & & \\
$5-10$ ha & & \\
$>10$ ha
\end{tabular}

E. Development programmes

E.1 Development assistance (past 5 years) from the government Type of programme Year Total no. of households Type of activity Level of success $^{a}$

a $1=$ very successful, $2=$ successful, $3=$ partly successful, $4=$ not very successful, $5=$ not at all successful

E.2 NGO assistance

Type of programme Year Total no. of households Type of activity Level of success $^{\mathrm{a}}$

a $1=$ very successful, $2=$ successful, $3=$ partly successful, $4=$ not very successful, $5=$ not at all successful 
E.3 Forestry activity

\begin{tabular}{lll}
\hline Type of programme Year Total no. of households Type of activity & $\begin{array}{l}\text { Level of } \\
\text { success }^{\mathrm{a}}\end{array}$
\end{tabular}

a $1=$ very successful, $2=$ successful, $3=$ partly successful, $4=$ not very successful, $5=$ not at all successful

F. Issues related to the forest and village

\begin{tabular}{l}
\hline Issues \\
Most villagers are not aware of the forest's status \\
Forest boundary is not clear \\
Forest boundary has been established but community \\
disagree \\
Community land is inside the forest area \\
Timber extraction by outsiders \\
Timber extraction by villagers \\
Animal/bird poaching \\
Disturbance of traditional activities inside the forest \\
Forestry officers confiscate equipment \\
Flooding and landslides \\
Forest pests \\
Forest fire (located around the village \\
Garden fire (located around the village \\
Famine \\
Land conflicts between villages \\
Land conflicts within village \\
Livestock theft \\
Cattle plague \\
Pest: locusts, mice, planthopper (wereng) \\
Outbreak of human disease \\
Drought, water shortage \\
Other ..........
\end{tabular}


Notes: 


\section{Questionnaire 2. Household survey}

\begin{tabular}{|c|c|}
\hline Province & : \\
\hline District & \\
\hline Subdistrict & \\
\hline Village & (1) \\
\hline
\end{tabular}

\section{Date}

Interviewer :

Note-taker :

\section{A. General information}

A.1 Household

A.1.1 Respondent's name :

A.1.2 Age :

A.1.3 Sex : $\square$ Male $\square$ Female

A.1.4 Are you the head of your household? $\square$ Yes (A.1.6) $\square$ No (A.1.5)

A.1.5 What is the household head's relationship to you?

Husband $\square$ Wife $\square$ Children $\square$ Other

A.1.6 Were you born in this village? $\square$ Yes $\square$ No

A.1.7 Are your ancestors from this village? $\square$ Yes $\square$ No

A.1.8 How many children in your

household? Male Female

A.1.9 How many children in the household are dependent on their parents/ guardians? Male Female

A.1.10 How many other people (not including the head of household, spouse and children) are dependent and living in the house? $\square$.......... Male $\square$.......... Female

A.1.11 Household composition

\begin{tabular}{lll}
\hline Age (years) & Male & Female \\
\hline $0-4$ & & \\
$5-14$ & & \\
$15-60$ & & \\
$>60$ & & \\
Total & & \\
\hline
\end{tabular}


A.2 Education level

A.2.1 Number of children who attend school

\begin{tabular}{ll}
\hline Education level & Male \\
\hline Primary school & \\
Junior high school & \\
High school & \\
University & \\
Total & \\
\hline
\end{tabular}

A.2.2 Highest education level obtained by family members

\begin{tabular}{llll}
\hline & Primary school Junior high school High school University \\
\hline Husband & & \\
Wife & & \\
Son(s) & & \\
Daughter(s) & & \\
\hline
\end{tabular}

B. Agricultural activities in the previous planting season

B.1 Agricultural system in the previous planting season

B.1.1 In the previous season, did you undertake agricultural activities Yes $\square$ No (B.1.3)

B.1.2 Do you own the land or rent it?

$\square$ Own (Table B.1.6) $\square$ Rent (Table B.1.8)

B.1.3 Do you own land that is used by other households?

$\square$ Yes (Complete B.1.8) $\square$ No

B.1.4 Does your land have a title (certificate)? $\square$ Yes $\square$ No

B.1.5 What kind of certificate do you have for your land?

Certificate Area (ha)
Ownership
Lease right (HGU)
Right to build (HGB)
Statement of customary land right (Girik)
Others


B.1.6 Agricultural activities in the previous season (use own land)

\begin{tabular}{|c|c|c|c|c|c|c|c|}
\hline Type of use & Area $^{a}$ & Distance $^{\mathrm{b}}$ & Location ${ }^{c}$ & KOD & $\begin{array}{l}\text { Main } \\
\text { crops }\end{array}$ & $\begin{array}{l}\text { Grown } \\
\text { since? }\end{array}$ & $\begin{array}{l}\text { Other } \\
\text { crops }\end{array}$ \\
\hline \multicolumn{8}{|l|}{ Food crops } \\
\hline \multicolumn{8}{|l|}{ Dry field } \\
\hline \multicolumn{8}{|l|}{ Garden } \\
\hline \multicolumn{8}{|l|}{ Home garden } \\
\hline \multicolumn{8}{|l|}{$\begin{array}{l}\text { Paddy field } \\
\text { (irrigation, swamp*) }\end{array}$} \\
\hline Grazing land & & & & & & & \\
\hline
\end{tabular}

Rubber

Coconut

a Local measurement if applicable, local measurement = ha or $\mathrm{m}^{2}$

b Distance is calculated as time required to travel to the site on foot (minutes)

c Direction and local name (if any)

*) select as appropriate

Complete the KOD using the land status reference (Table B.1.7)

B.1.7 Land and Forest Status (KOD)
A. Ownership/Control over forestland
B. Use
By law:
1. Used by the state
1. State forest
2. Communal use
2. Private forest
3. Used by individuals
3. Customary forest
4. Used without permission
4. Private property
5. Used with permission (borrowing)
5. Right of exploitation (HGU), right to build (HGB) and forest concession (HPH)
By customs/tradition:
1. Customary forest
2. Private land 
B.1.8 Agricultural activities in the previous season - rent or borrow land

\begin{tabular}{|c|c|c|c|c|c|c|c|}
\hline Type of use & Area $^{a}$ & Distance $^{b}$ & Location & KOD & $\begin{array}{l}\text { Grown } \\
\text { since? }\end{array}$ & $\begin{array}{l}\text { Other } \\
\text { crops }\end{array}$ & $\begin{array}{l}\text { Payment } \\
\text { system }\end{array}$ \\
\hline \multicolumn{8}{|l|}{ Food crops } \\
\hline \multicolumn{8}{|l|}{ Dry field } \\
\hline \multicolumn{8}{|l|}{ Garden } \\
\hline \multicolumn{8}{|l|}{ Home garden } \\
\hline \multicolumn{8}{|l|}{$\begin{array}{l}\text { Paddy field } \\
\text { (irrigation, swamp*) }\end{array}$} \\
\hline Grazing land & & & & & & & \\
\hline
\end{tabular}

Rubber

Coconut

\footnotetext{
a Local measurement if applicable, local measurement $=\ldots$ ha or $\mathrm{m}^{2}$

b Distance is calculated as time required to travel to the site on foot (minutes)

c Direction and local name (if any)

*) select as appropriate

Complete the KOD using the land status reference (Table B.1.7)
}

B.2 Use of agricultural inputs in the previous planting season

B.2.1 Did you use seeds/fertilizer/insecticides in the previous planting season?

$$
\text { Yes (Fill in B.2.2) } \square \text { No (B.3) }
$$

B.2.2 Agricultural input for food crops

\begin{tabular}{llllllllllll}
\hline Commodities & Seed & Fertilizer & & & Herbicide & Insecticide & Fungicide \\
\cline { 2 - 4 } & $\mathrm{Kg}$ & $\mathrm{Rp}$ & $\begin{array}{l}\text { Name of } \\
\text { fertilizer }\end{array}$ & $\mathrm{Kg}$ & $\mathrm{Rp}$ & $\mathrm{Kg}$ & $\mathrm{Rp}$ & $\mathrm{Kg}$ & $\mathrm{Rp}$ & $\mathrm{Kg}$ & $\mathrm{Rp}$ \\
\hline
\end{tabular}

Paddy

Maize 
B.2.3 Production input for plantations

\begin{tabular}{llllllllllll}
\hline Commodities & Seed & Fertilizer & & & Herbicide & Insecticide & Fungicide \\
\cline { 2 - 4 } & $\mathrm{Kg}$ & $\mathrm{Rp}$ & $\begin{array}{l}\text { Name of } \\
\text { fertilizer }\end{array}$ & $\mathrm{Kg}$ & $\mathrm{Rp}$ & $\mathrm{Kg}$ & $\mathrm{Rp}$ & $\mathrm{Kg}$ & $\mathrm{Rp}$ & $\mathrm{Kg}$ & $\mathrm{Rp}$ \\
\hline
\end{tabular}

Rubber

B.3 Labour

B.3.1 Do you employ labour outside your family?

B.3.2 Cost of labour: Food crops (previous season)

\begin{tabular}{clllll}
\hline Commodities & \multicolumn{2}{l}{ Labour cost (in rupiah) } & & & \\
\cline { 2 - 3 } & $\begin{array}{l}\text { Land } \\
\text { preparation/ } \\
\text { ploughing }\end{array}$ & waintenance/ & Harvesting & $\begin{array}{l}\text { Post- } \\
\text { harvesting }\end{array}$ & $\begin{array}{l}\text { Marketing } \\
\text { (including } \\
\text { transport) }\end{array}$ \\
\hline
\end{tabular}

Paddy

Maize

B.3.3 Cost of labour: Plantation (previous season)

\begin{tabular}{clllll}
\hline Commodities & \multicolumn{2}{l}{ Labour cost (in rupiah) } & & & \\
\cline { 2 - 6 } & $\begin{array}{l}\text { Land Planting } \\
\text { preparation/ } \\
\text { ploughing }\end{array}$ & $\begin{array}{l}\text { Maintenance/ } \\
\text { weeding }\end{array}$ & Harvesting & $\begin{array}{l}\text { Post- } \\
\text { harvesting }\end{array}$ & $\begin{array}{l}\text { Marketing } \\
\text { (including } \\
\text { transport) }\end{array}$ \\
\hline
\end{tabular}

Rubber 


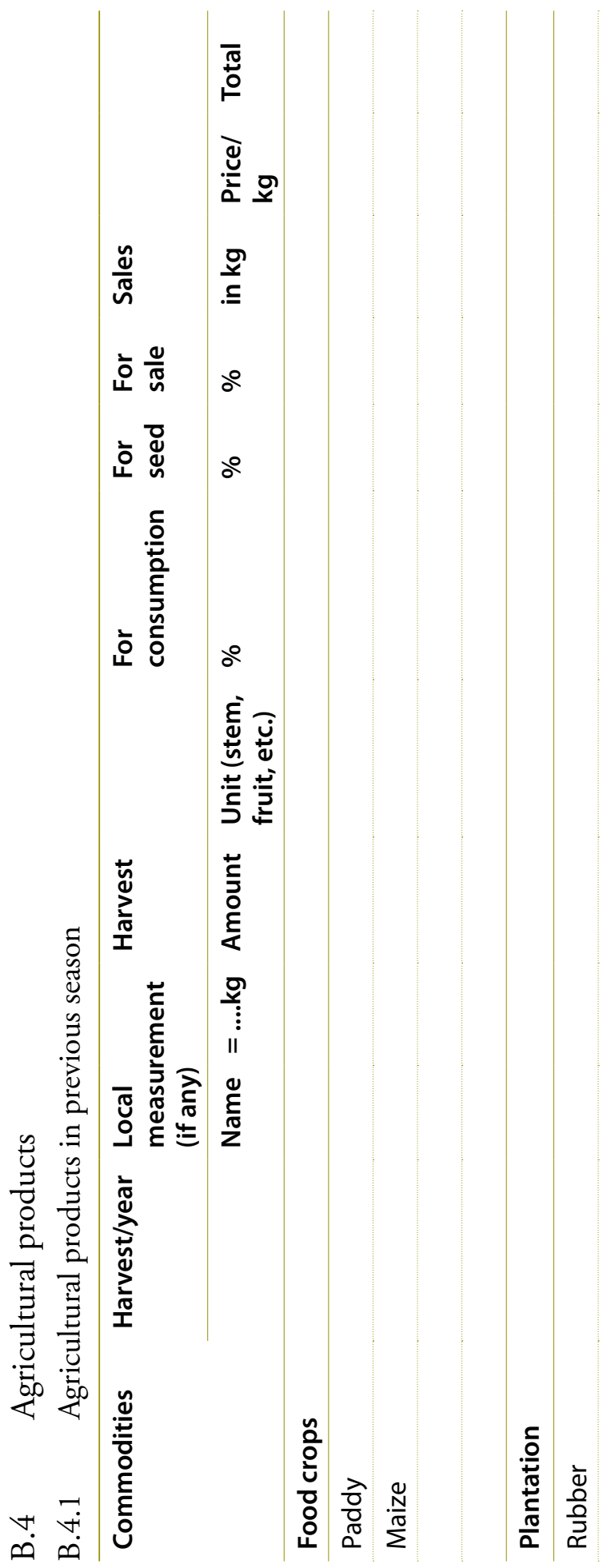


C. Land use information for the current planting season

C.1.1 What kind of land is being used this season?

C.1.2 Have you cleared any new plots of land since the last planting season?

C.1.3 Do you plan to expand your land or clear new land?

C.1.4 Do you plan to replace your crops with new crops?

C.1.5 Do you plan to decrease the use of the land?

C.1.6 Do you plan to leave your land fallow?

C.1.7 Land use for current planting season

\begin{tabular}{|c|c|c|c|}
\hline & Dry field & Garden & Plantation \\
\hline C.1.1 & Same/Different & & \\
\hline \multirow{2}{*}{$\begin{array}{l}\text { Land used in the current } \\
\text { season }\end{array}$} & Area & & \\
\hline & Other crops & & \\
\hline C.1.2 & Yes/No & & \\
\hline \multirow{3}{*}{$\begin{array}{l}\text { Cleared new plots since last } \\
\text { planting season }\end{array}$} & Area & & \\
\hline & Location & & \\
\hline & KOD & & \\
\hline C.1.3 & Yes/No & & \\
\hline \multirow{3}{*}{$\begin{array}{l}\text { Plan to expand the land area } \\
\text { or clear new land }\end{array}$} & Area & & \\
\hline & Location & & \\
\hline & KOD & & \\
\hline \multirow{3}{*}{$\begin{array}{l}\text { C.1.4 } \\
\text { Plan to replace crops }\end{array}$} & Yes/No & & \\
\hline & Area & & \\
\hline & Type of crops & & \\
\hline \multirow{4}{*}{$\begin{array}{l}\text { C.1.5 } \\
\text { Plan to decrease the area }\end{array}$} & Yes/No & & \\
\hline & Area & & \\
\hline & Location & & \\
\hline & KOD & & \\
\hline \multirow{4}{*}{$\begin{array}{l}\text { C.1.6 } \\
\text { Plan to leave the land fallow }\end{array}$} & Yes/No & & \\
\hline & Area & & \\
\hline & Location & & \\
\hline & KOD & & \\
\hline
\end{tabular}

Complete the KOD using the land status reference (Table B.1.7) 
C.2 Do you think you will still be able to use your current land for all of the next 5 years?

No (go to C.3) $\square$ Uncertain $\square$ Yes

C.3 Reasons for not being able to use the current land for all of the next 5 years:

a. No land certificate

b. I only have temporary access

c. The land is rented

d. The rights over land can be revoked at any time

e. Land rights are not enforced

f. The government may limit use

g. Competition among villagers

h. Competition with neighbouring villages

i. Competition with private investors (outside company)

j. Infrastructure/road development

$\mathrm{k}$.

1 .

Note: If the respondent selects more than one option, ask him/ her to rank the choices in order of importance.

D. Livestock and fisheries

D.1 Do you raise livestock?

Yes, raised by myself (complete D.1.1)

Yes, raised with other people (complete D.1.6)

No (D.1.7) 


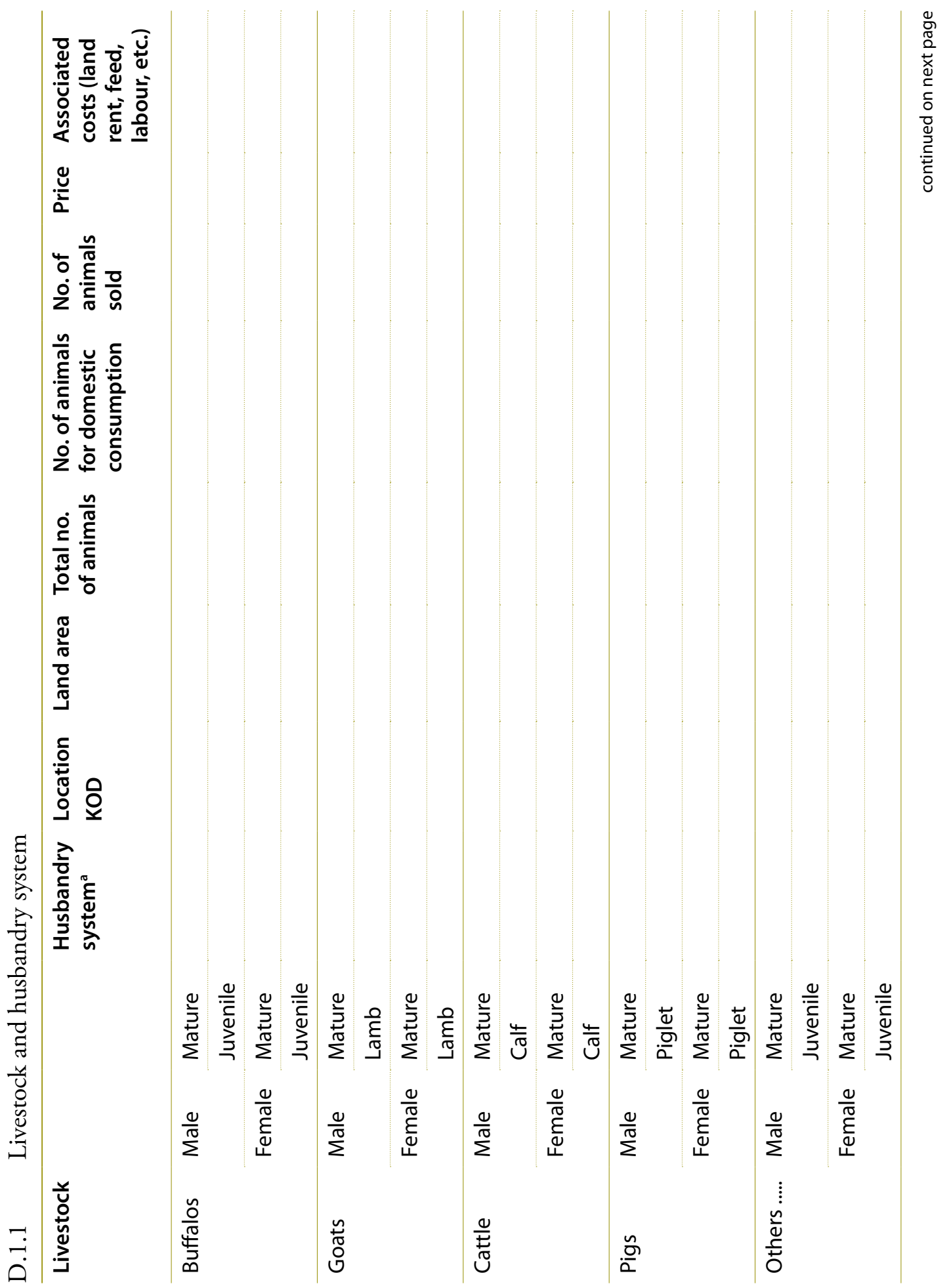







D.1.2 Products derived from animal husbandry

\begin{tabular}{|c|c|c|c|c|c|}
\hline & Total harvest & Unit & $\%$ consumed & $\%$ sold & Price/unit \\
\hline Milk & & & & & \\
\hline Butter & & & & & \\
\hline Leather & & & & & \\
\hline Fertilizer & & & & & \\
\hline
\end{tabular}

D.1.3 If someone else looks after your animals, what is the sharing mechanism?

Who bears the cost? How much? Rp .......... Sharing system:

How much does the owner get? Rp .........../year

D.1.4 Do you look after someone else's animals?

$\square$ Yes (complete D.1.6) $\square$ No (go to D.1.7)

D.1.5 If you look after someone else's animals, how are you paid?

How much do you earn for looking after their animals?

Payment system .......... Revenue Rp ........../year

D.1.6 Looking after someone else's animals

\begin{tabular}{lllll}
\hline Livestock & $\begin{array}{l}\text { Husbandry } \\
\text { system }^{\mathrm{a}}\end{array}$ & Land area & $\begin{array}{l}\text { Location } \\
\text { KOD }\end{array}$ & $\begin{array}{l}\text { Number of } \\
\text { animals }\end{array}$ \\
\hline
\end{tabular}

Buffalos

Goats/sheep

Cattle

Pigs

Chickens

Ducks

a $1=$ wild, $2=$ tethered, $3=$ stabled at night, $4=$ grazing, $5=$ permanently stabled

Complete the KOD using the land status reference (Table B.1.7) 
D.1.7 Do you farm inland fisheries? $\square$ Yes (Table D.1.7.1) $\square$ No

D.1.7.1 Fisheries - Fish ponds, fish cages

\begin{tabular}{|c|c|c|}
\hline Component & Description & Unit \\
\hline Area & & $\mathrm{Ha}$ \\
\hline Number of ponds/cages & & Item \\
\hline \multicolumn{3}{|l|}{ Period of rearing } \\
\hline Purpose $^{b}$ & & \\
\hline
\end{tabular}

Fish harvest:\% for consumption\% for sale

Rearing cost

Rp/year

Annual sales

Rp/year

a $1=$ whole year, 2 = seasonal

b $1=$ for consumption, $2=$ for sale

D.1.8 Do you earn any income from river, lake or marine

fisheries? $\square$ Yes $\square$ No

\section{Component}

Harvest \#1 Harvest \#2 Harvest \#3

Land status, KOD

Catch

Time to reach fishing site ${ }^{a}$

Who goes on fishing trips ${ }^{b}$

Duration of fishing trips ${ }^{c}$

Frequency of fishing trips $^{d}$

Time that fishing is suspended because of

weather/season ${ }^{\mathrm{e}}$

Total catch per trip

Catch unit

$\%$ for consumption

$\%$ for sale

Price/unit

Cost per fishing trip

a Time to reach fishing site: $1=$ less than 1 hour, $2=2-4$ hours, $3=4-8$ hours, $4=$ more than 8 hours

b Who: $1=$ husband, $2=$ wife, $3=$ husband and wife, $4=$ husband and children, $5=$ wife and children, $6=$ children, $7=$ whole family

c Duration of trip: $1=$ less than 6 hours, $2=$ half a day, $3=$ a whole day, $4=2$ days, $5=$ more than 2 days

d Frequency of trips: $1=$ every day, $2=$ once a week, $3=$ twice a month, $4=$ one a month, $5=$ six times a year, $6=$ twice a year, $7=$ once a year

e Time that fishing is suspended because of weather/season: $1=1$ week, $2=2$ weeks,

$3=1$ month, $4=2$ months, $5=3$ months, $6=$ more than 3 months

Complete the KOD using the land status reference (Table B.1.7) 
E. Issues and problems related to agriculture/plantation/animal husbandry/fisheries

- Please record any spontaneous responses regarding problems/issues

E.1 Problems related to agricultural activities?

\begin{tabular}{lcll}
\hline Problems Often Sometimes Rarely & $\begin{array}{l}\text { Importance } \\
\text { ranking }\end{array}$
\end{tabular}

Wild boar invasion

Other animal invasion (birds,

squirrels, bats, cattle, etc.)

Other pests

Lack of capital

Insufficient land

No clear land status

Difficulties accessing quality seed

Difficulties accessing fertilizer

Fertilizer is too expensive

Difficulties selling products

Farm gate price is very low

Lack of technology information

Lack of water for agriculture

Floods

Land conflict with company

Other

E.2 Have you experienced any of these situations in the past 2 years?

If so, how did you respond/cope?

\section{Vulnerability issue}

Yes/No*) Response to cope with the issue

A sudden shortfall of income

Crop failure

Natural hazards (flood,

drought, earthquake, wind

storm, plant disease, pests ${ }^{*}$ )

House eviction by

Land eviction by 
E.2 Continued

Vulnerability issue Yes/No*) Response to cope with the issue

House fire

Other

F. Extension, rural development and social organisation

F.1 Have you been visited by a field extension officer in the past two years? $\square$ Yes $\square$ No

F.1.1 Extension

Extension workers

Extension topic

Frequency

Agricultural extension officer (PPL)

Family planning officer (KB)

Forestry officer

Other

F.2 Have you ever received assistance or participated in a rural development programme undertaken by an external organisation (government, NGO, etc.) $\square$ Yes $\square$ No

F.2.1 Rural development assistance in the past 5 years

\begin{tabular}{|c|c|c|c|c|}
\hline Year & $\begin{array}{l}\text { Name of } \\
\text { programme }\end{array}$ & $\begin{array}{l}\text { Organisation } \\
\text { focal point }\end{array}$ & $\begin{array}{l}\text { Description of } \\
\text { activities }\end{array}$ & Level of success ${ }^{a}$ \\
\hline
\end{tabular}

a $1=$ very successful, $2=$ successful, $3=$ somewhat successful, $4=$ not very successful, $5=$ not at all successful

F.3 Are you a member of any organisations?

F.3.1 Organisation membership

\begin{tabular}{lll}
\hline Name of organisation $\begin{array}{l}\text { Organisation } \\
\text { status }^{\mathrm{a}}\end{array}$ & $\begin{array}{l}\text { Membership Description of activities } \\
\text { since? }\end{array}$
\end{tabular}

a 1 = formal, 2 = informal 


\section{G. $\quad$ Forest products}

G.1 Do you collect non-timber forest products? $\square$ Yes $\square$ No (G.2)

G.1.1 Use of non-timber forest products (NTFPs)

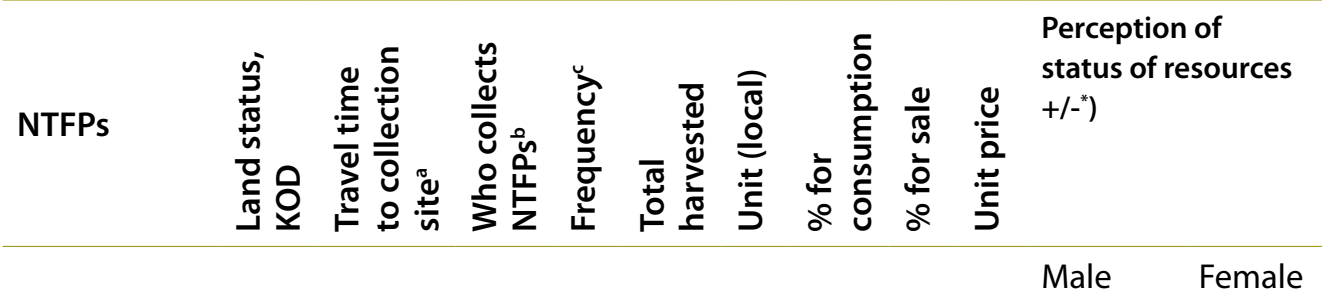

\section{Orchids}

Honey

\section{Rattan}

Leaves for

roofs

Vegetables

Wild boar

Rubber latex

Medicinal

plants

a Travel time: $1=$ less than 1 hour, $2=2-4$ hours, $3=4-8$ hours, $4=$ more than 8 hours

b Who: $1=$ husband, $2=$ wife, $3=$ husband and wife, $4=$ husband and children, $5=$ wife and children, 6 = children, 7 = whole family

c Frequency: 1 = every day, 2 = once a week, $3=$ twice a month, $4=$ once a month, $5=$ six times a year, $6=$ twice a year, $7=$ once a year

Complete the KOD using the land status reference (Table B.1.7)

G.2 Do you think that you will have access to the current forest resources for the next 5 years?
$\square$ No (go to G.3) $\square$ Uncertain $\square$ Yes

G.3 Reasons for not having access to the current forest resources for the next 5 years:
a. No clear forest status
b. No clear forest boundary
c. Rights to the land can be revoked at any time 

d. Land rights are not enforced
e. Government limits the use
f. Competition among villagers
g. Competition with neighbouring villages
h. Competition with private investors (outside company)
i. Infrastructure/road development
j.

Note: If the respondent selects more than one answer, ask him/ her to rank the items in order of importance

\section{G.4 Timber products}

G.4.1 Timber use (fuelwood and sawnwood)

Species name
Location of timber-collection site ${ }^{\mathrm{a}}$
Land status, KOD
Time to reach collection site ${ }^{\mathrm{b}}$
Who collects the timber
Duration of timber collection trip ${ }^{\mathrm{d}}$
Frequency of timber collection
Total collected
Unit (bundle, branches or $\left.\mathrm{m}^{3}, \ldots . . . . ..\right)$
$\%$ for own consumption
$\%$ for sale
Price per unit
a Location: $1=$ forest, $2=$ field, $3=$ secondary forest
b Travel time: $1=$ less than 1 hour, $2=2-4$ hours, $3=4-8$ hours, $4=$ more than 8 hours
c Who: $1=$ husband, $2=$ wife, $3=$ husband and wife, $4=$ husband and children, $5=$ wife and
children, $6=$ children, $7=$ whole family
d Duration of trip: $1=$ less than 6 hours, $2=$ half a day, $3=$ one day, $4=2$ days, $5=$ more than
2 days
e Frequency: $1=$ every day, $2=$ once a week, $3=$ twice a month, $4=$ every month, $5=$ six times
a year, $6=$ twice a year, $7=$ once a year
Complete the KOD using the land status reference (Table B. 1.7$)$


H. Perceptions of changes

H.1 During the past 5 years, have you noticed any change in the availability of forestland that can be cleared?
a. Increase
b. No change
c. Decrease
d. Do not know

H.2 If the availability of forestland for clearing is INCREASING, why?
a. Less competition among villagers
b. Less competition with neighbouring villages
c. Relaxation of government regulations
d. Other

H.3 If the availability of forestland for clearing is DECREASING, why?
a. Competition among villagers
b. Competition with neighbouring villages
c. Stricter government restrictions
d. Other
e.

H.4 In the past 5 years, have you noticed a change in forest product collection?
a. Increase, because
b. No change
c. Decrease, because
d. Do not know

H.5 In the past 5 years, have you noticed a change in the amount of income generated from forest products:
a. Increase, because
b. No change
c. Decrease, because
d. Do not know

H.6 How is your family's economic situation compared with 5 years ago?
a. Better, because
b. No change
c. Worse, because 
I. Intergenerational perceptions of the forest

\begin{tabular}{lllll}
\hline Name & Sex Age & Generation & \\
\cline { 3 - 4 } & & Grandparents Self & Grandchildren \\
\hline
\end{tabular}

J. Other income

J.1 Which activities do you consider as your main sources of livelihood?
Agriculture $\square$ Plantation $\square$ Animal husbandry
Fisheries $\square$ Forestry $\square$ Other....

J.2 Do you have any sources of income apart from agriculture, plantation, animal husbandry, fisheries or forestry?

$\square$ Yes $\square$ No (end of questionnaire)

J.3 What is the source of income?

J.4 The income source is $\square$ Permanent $\square$ Seasonal

J.5 How does the other income compare with income from main activities?

$\square$ Larger $\square$ Same $\square$ Smaller

J.6 How much do you earn from your alternative sources of income each year? Rp

K. Assets

K.1 Observe and ask about what assets the respondent owns

\begin{tabular}{|c|c|c|c|c|}
\hline Description & Total & Since & Price (Rp) & Note \\
\hline \multicolumn{5}{|c|}{ Electricity generator } \\
\hline \multicolumn{5}{|l|}{ Petromak lights } \\
\hline \multicolumn{5}{|l|}{ Satellite dish } \\
\hline \multicolumn{5}{|l|}{ Radio/tape player } \\
\hline Television & & & & \\
\hline
\end{tabular}


K.1 Continued

\begin{tabular}{|c|c|c|c|c|}
\hline Description & Total & Since & Price (Rp) & Note \\
\hline \multicolumn{5}{|l|}{ Chainsaw } \\
\hline \multicolumn{5}{|l|}{ Refrigerator } \\
\hline \multicolumn{5}{|l|}{ Bicycle } \\
\hline \multicolumn{5}{|l|}{ Motorcycle } \\
\hline \multicolumn{5}{|c|}{ Outboard motor } \\
\hline \multicolumn{5}{|c|}{ Rowing boat, long boat } \\
\hline \multicolumn{5}{|c|}{ Sewing machine } \\
\hline \multicolumn{5}{|c|}{ Antique porcelain jar } \\
\hline \multicolumn{5}{|l|}{ Camera } \\
\hline \multicolumn{5}{|l|}{ Rifle } \\
\hline \multicolumn{5}{|c|}{ Rice-milling machine } \\
\hline \multicolumn{5}{|l|}{ Car } \\
\hline \multicolumn{5}{|c|}{ Mobile phone } \\
\hline \multicolumn{5}{|l|}{$\ldots \ldots \ldots . .}$. \\
\hline ............ & & & & \\
\hline
\end{tabular}

K.2 Control Sheet

\begin{tabular}{llll}
\hline Household expenditure & Monthly & Annually & Total \\
\hline Routine expenditure & & & \\
\hline Food and
\end{tabular}

Food and drink

Energy (electricity, fuelwood, cooking gas,

kerosene)

Transport (including gasoline)

Sanitation (soap, detergent,

Clothes, shoes

Education

Health

Loan repayment

Cigarettes

Routine donations

Other

Total 
K.2 Continued

\begin{tabular}{|c|c|c|c|}
\hline Household expenditure & Monthly & Annually & Total \\
\hline \multicolumn{4}{|l|}{ Irregular expenditure (investment, etc.) } \\
\hline House & $\operatorname{xxxxxxx}$ & & \\
\hline Transport (motorcycle, car.....) & $x x x x x x x$ & & \\
\hline Land & $\operatorname{xxxxxxx}$ & & \\
\hline Cattle & $\operatorname{xxxxxxx}$ & & \\
\hline Chainsaw & $x x x x x x x$ & & \\
\hline Other tools/machines & $\operatorname{xxxxxxx}$ & & \\
\hline Gold & $\operatorname{xxxxxxx}$ & & \\
\hline Donation for family, religious purposes, etc. & $\operatorname{xxxxxxx}$ & & \\
\hline \multicolumn{4}{|l|}{ Health } \\
\hline Other ............. & $x x x x x x x$ & & \\
\hline Total & $\operatorname{xxxxxxx}$ & & \\
\hline \multicolumn{4}{|l|}{ Irregular income or sales } \\
\hline Motorcycle/car & $\operatorname{xxxxxxx}$ & & \\
\hline Land & $x x x x x x x$ & & \\
\hline Cattle & $x x x x x x x$ & & \\
\hline Chainsaw & $x x x x x x x$ & & \\
\hline Other tools/machines & $\operatorname{xxxxxxx}$ & & \\
\hline Loans & $x x x x x x x$ & & \\
\hline Family assistance (remittance, loans, etc.) & $x x x x x x x$ & & \\
\hline Gold sales & $x x x x x x x$ & & \\
\hline Other ............. & $x x x x x x x$ & & \\
\hline Total & xxxxxxx & & \\
\hline \multicolumn{4}{|l|}{ Income from rental } \\
\hline \multicolumn{4}{|l|}{ Buffalo/horse } \\
\hline \multicolumn{4}{|l|}{ Motorcycle/car } \\
\hline \multicolumn{4}{|l|}{ Chainsaw } \\
\hline \multicolumn{4}{|l|}{ House/room } \\
\hline \multicolumn{4}{|l|}{ Other ........... } \\
\hline \multicolumn{4}{|l|}{ Total } \\
\hline Total & & & \\
\hline
\end{tabular}




\section{Questionnaire 3. Focus group discussion}

(Group: gender, age group, ethnicity and livelihoods)

$\begin{array}{ll}\text { Province : } \\ \text { District } \\ \text { Subdistrict } & : \\ \text { Village } & : \\ \text { Group : } \\ \text { Participants : }\end{array}$

Date :
Interviewer :
Note-taker :

\section{A. Rights to forest resources, enforcement and compliance}

1. What do you know about 'rights to land' or 'rights to forest resources'?

a. Do you know of any rules (customary or state law) that affect your rights to land or forest resources? Please list and explain. How do you understand these rules?

b. Who owns forests under the law? Do the villagers have any rights or a certificate?

2. How do you see forests?
a. as sacred/holy places
b. as economic resources
c. both of the above
d. other (please explain)

Please explain why you say this and how this perception affects your use of the forest.

3. How do you use the land and the forest resources?

What are the main products that you collect from the forest? Sort them by order of importance. (List three types of product for subsistence and three types of product for sale) 
Do you collect these products seasonally or year-round?

4. What are other benefits of the forest? (in terms of forest management activities or community forestry)

How are the benefits associated with employment, income, etc. distributed among the villagers?

Are you satisfied with this distribution? If not, why?

Please give examples.

How could profit sharing between forest users be improved? Please rate your suggestions.

5. What attributes should locals possess to be allowed to enter the forest for these purposes: recreational, religious or other non-consumption purposes? (Examples of attributes: certain clan/tribe, religion, male, female, old, young)

\section{B. Forest management}

6. In your opinion, how many (according to local standards) of your needs are met by collecting products from the forest? For example, fodder, firewood, housing, food or other needs, etc. (For three subsistence products and three sales products)

Has the amount of the products that you need increased or decreased during the past 5-10 years? Explain the reasons for the decrease or increase and rank the products in order of importance (Use the following table to create a list of forest products used and ranks the top three subsistence products and three sales products, plants and animals).

\begin{tabular}{llll}
\hline Forest product & 2000 & 2005 & 2010 \\
\hline
\end{tabular}


7. What are your responsibilities towards the forest (in terms of forest conservation and management functions)? Use the following table to provide details.

Management functions
Actors apparently involved (internal and external)

Defining/protecting borders of natural resources

Developing/enforcing rules/ regulations

Monitoring compliance

Resolving conflicts

Providing leadership/organisation

Assessing fines/sanctions

Example: If forest users are required to improve the condition of the forest through forest regeneration activities or other activities (e.g. preventing/ terminating encroachment by invasive species, creating a nursery to distribute seeds, reducing harvest level, investing in technologies for forest improvements such as beekeeping, tree planting or other methods to protect, maintain or enhance forest resources).

a. If so, please specify. How often did you perform the activities mentioned above last year?

b. Are there any particular village members who try to limit the harvest of forest products from other communal land or forestland owned by the government?

c. If yes, which parts of the forest have been used so intensively as to limit the use of the forest in this village? (e.g. privately owned forest, government forest, communal forest to which other groups have a legal right)

d. Have any restrictions been placed on the harvest of forest products during the past 5 years? If yes, what are the changes? What is the basis for such restrictions? 
e. Do you think villagers follow the rules for harvesting, processing or selling forest products or using forests for non-consumption purposes?

- Never or rarely

- Occasionally

- Often

- Almost always

Please explain your answer.

f. In your opinion, what are the most serious problems for forest management for the next 5 years? How do you think these problems can be solved?

g. In your opinion, what opportunities will arise in the next 5 years in relation to forest management? How can these opportunities be realised? What needs to be done? Who should be involved?

\section{Perception of future access to land}

8. Do you think you will continue to have access to land and forest resources during the next 5 years?

a. Explain your view and your reasons for that view.

b. If the perception is negative: What must be done to alleviate the fear/ doubt? What actions can be taken to make your rights to land and the forest more secure? With whom? What are the responsibilities of (your village)?

9. Has tree density in the forest changed during the past 5 years? If yes, please specify the three main reasons for the changes in tree density.

10. During the past 5 years, have there been any changes in vegetation areas in the forest? If they increased, please give three reasons for the increase. If they decreased, please give three reasons for the decrease. 


\section{Development projects in the village}

11. What development projects have taken place in this village during the past 10 (ten) years to enhance community participation?

a. Have any projects focused on access/rights to land and forest and their management? (including climate change, medicinal plants, etc.)

b. Have there been any specific projects to promote villagers' rights and ownership?

c. Have there been any particular projects to promote women's and men's participation in forest management? Describe these projects.

- Project title:

- Sponsors (NGO/government/donor):

- Objectives and key activities:

- Activity period:

12. How successful was the project?
a. Very successful
b. Quite successful
c. Not successful
d. Quite unsuccessful
e. Not at all successful

Please explain who you say this. If the project failed, mention three ways the failure could have been avoided. 
FGD results report

\begin{tabular}{ll}
\hline Date: & Facilitator: \\
\hline Time: & Note-taker:
\end{tabular}

Village:

Discussion participants:

Notes on discussion

Main discussion topics

How easily was consensus achieved? (difficult/easy)? Explain.

Record some interesting quotations from the opinions

Were there any specific or unexpected findings?

Spontaneous and relevant discussion during recess or after the discussion was closed 


\section{Questionnaire 4. In-depth interview with key informants}

(Village head, Customary chief, Prominent villager, Clan head)

$\begin{array}{ll}\text { Province } & : \\ \text { District } & : \\ \text { Subdistrict } & : \\ \text { Village } & : \\ \text { Informant's name/ } & : \\ \text { Age/Tribe/Clan } & \text { : }\end{array}$

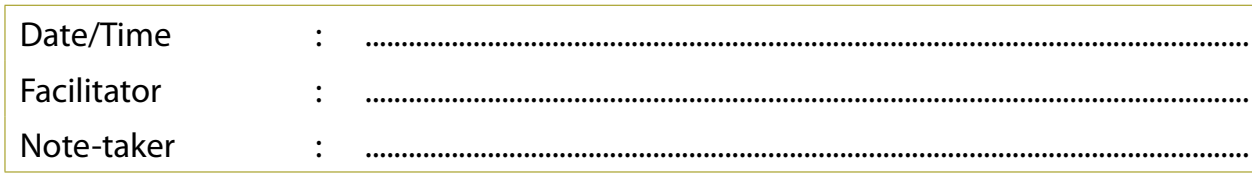

\section{A. Related institutions' forest arrangements}

1. Does this village have formal and/or non-formal rules (including customary norms, myths, traditions) concerning using or entering the forest (also consider the spirit world, which underlies the tradition that allows (or prohibits) access to the forest)?

Do these rules apply differently to men and women? Please explain.

2. Are there any special rules that limit the following activities in the forests?

a. Maintenance/Rehabilitation (e.g. eradicate invasive species; enhance regeneration; build perimeter fences to prevent cattle wandering into the forests, etc.). If yes, explain. Who made these rules (village or local government)?

b. Harvesting of forest products (e.g. products to be harvested, harvest time, quantity/year). If yes, explain. Who made these rules (village or local government)?

c. Are there rules that restrict other activities, such as processing and sale of forest products? If yes, please explain. Who made the rules (village or local government)? Are there processed products for personal consumption or trade? 
3. How are villagers penalised for violating the forest rules:
a. First offence?
b. Second offence?
c. Repeated offence?

Who decides to impose the penalty?

4. a. Who in the village is responsible for making the forest rules? How do you describe them?

b. What are the characteristics of people who do not have any rulemaking power? Are they from a particular religious group, tribal group, gender group?

5. If customary/village rules are established, to what extent do the villagers comply with the rules?
a. No villagers comply
b. Some villagers comply
c. About half $(50 \%)$ of the villagers comply
d. Most villagers comply
e. All villagers comply

6. If a villager who uses the forest loses his/her right to harvest/take certain forest products, how can this right be restored?

7. During the past 5 years, have any outsiders (e.g. government officials) been asked to impose a penalty on villagers who violate the rules? If yes, please describe the incident. 


\section{B. Threats and conflicts}

8. Who uses the forest in the village?

a. The villagers, members of a certain clan or tribe, people from other villages?

b. Who are they and where are they from?

c. How often do they use the forest in this area?

d. Which forests do they use and for what?

e. Do they need a permit to use the forest? Who gives them the use permits? Village head? Customary chief? Subdistrict head?

9. If the people who use the forest in this region come from a different clan or tribe, how well do they understand the prevailing rules? Do they follow the rules?

10. Have there been any conflicts related to land and forest use among clans or tribes in this village during the past 5 years?

a. If yes, please explain the origins of the conflict and how the conflict was resolved.

b. How long did it take to resolve the conflict?

c. What challenges arose in trying to resolve the conflict?

11. Have there been differences of opinion or conflicts regarding access to the forest or land allocation with parties outside this village during the past 5 years?

a. If yes, who were the outside parties? (e.g. NGOs, agencies, government departments, others) 
b. When did the conflict start and end?

c. What were the underlying reasons for the conflict?

d. How was the conflict resolved?

e. Who was involved in resolving the conflict?

f. How did they resolve the conflict?

g. Was anyone dominant in resolving the conflict? Who were they and what did they do?

h. Were you satisfied with how the conflict was settled? If not, what did you do to remedy your dissatisfaction? Did you succeed? What were the main obstacles you faced when resolving the conflict?

12. During the past 5 years, have there been any problems that caused conflicts over access to forest or land allocation among the villagers?

a. If yes, describe the conflict.

b. How are internal conflicts in this village resolved?

c. Is there an established procedure or mechanism to resolve such conflicts?

d. What are the main obstacles to resolving such conflicts in this village?

e. What can be done to help to improve the management of conflict and resolve conflicts internally? 
13. How would you describe changes in the level of conflict within the group during the past 5 years (please explain)?
a. Increased
b. Unchanged
c. Decreased
d. Interfered with daily activities
e. Annoying at times
f. Channelled in ways that do not interfere with daily activities

14. How do the villagers express their wishes and concerns about the land and the forests to the relevant authorities (e.g. local authorities, government officials, etc.)? You can select more than one answer.
a. Official petition
b. Formal hearings
c. Demonstration
d. General meeting
e. Taking officials hostage in exchange for something (illegally)
f. Others (please specify)

15. If any of the above were used, describe the situation.

What was the villagers' wish/demand?

Did the government handle the problem? If not, why not? If yes, were you satisfied with their solution? 


\section{Note 9 - Experiences from the CoLUPSIA project}

The CoLUPSIA project is a research project funded by the European Commission. This project was implemented by CIRAD (Centre de coopération internationale en recherche agronomique pour le développement) in collaboration with its research institution partners, CIFOR (Center for International Forestry Research), University Pattimura in Ambon, University Gadjah Mada in Yogyakarta and NGOs (Telapak, HuMA, TOMA and Riak Bumi).

A core component of the CoLUPSIA project was the completion of socioeconomic surveys (household survey and village profile), along with focus group discussions and interviews with key informants, in villages in Kapuas Hulu in the province of West Kalimantan and Central Maluku (Seram Island) in the province of Maluku. Following are some key facts and figures.

- The village samples were selected from pilot areas: four in Kapuas Hulu and five in Central Maluku. The interviews were collected in pilot areas in each district, as shown in Figures 2 and 3.




- During 2010 and 2011, 566 households were interviewed in Central Maluku and 800 in Kapuas Hulu.

- A total of 39 village-level surveys were completed (20 in Kapuas Hulu and 19 in Central Maluku).

- One hundred key informant surveys were completed (40 in Kapuas Hulu and 60 in Central Maluku).

- Data were collected, cleaned and analysed using SPSS, Excel and nVivo (qualitative data analysis software).

The information collected was used to produce two reports summarising the findings in each district. These two reports are available separately.

The survey results will be used as baseline data for land use planning, and also to highlight pertinent issues - constraints and opportunities - facing communities with regard to land use and the potential mechanisms for addressing these issues. Robust socio-economic baseline data can be combined with biophysical data to provide a thorough overview of the situation within the study areas. Understanding the communities and their internal and external (e.g. government

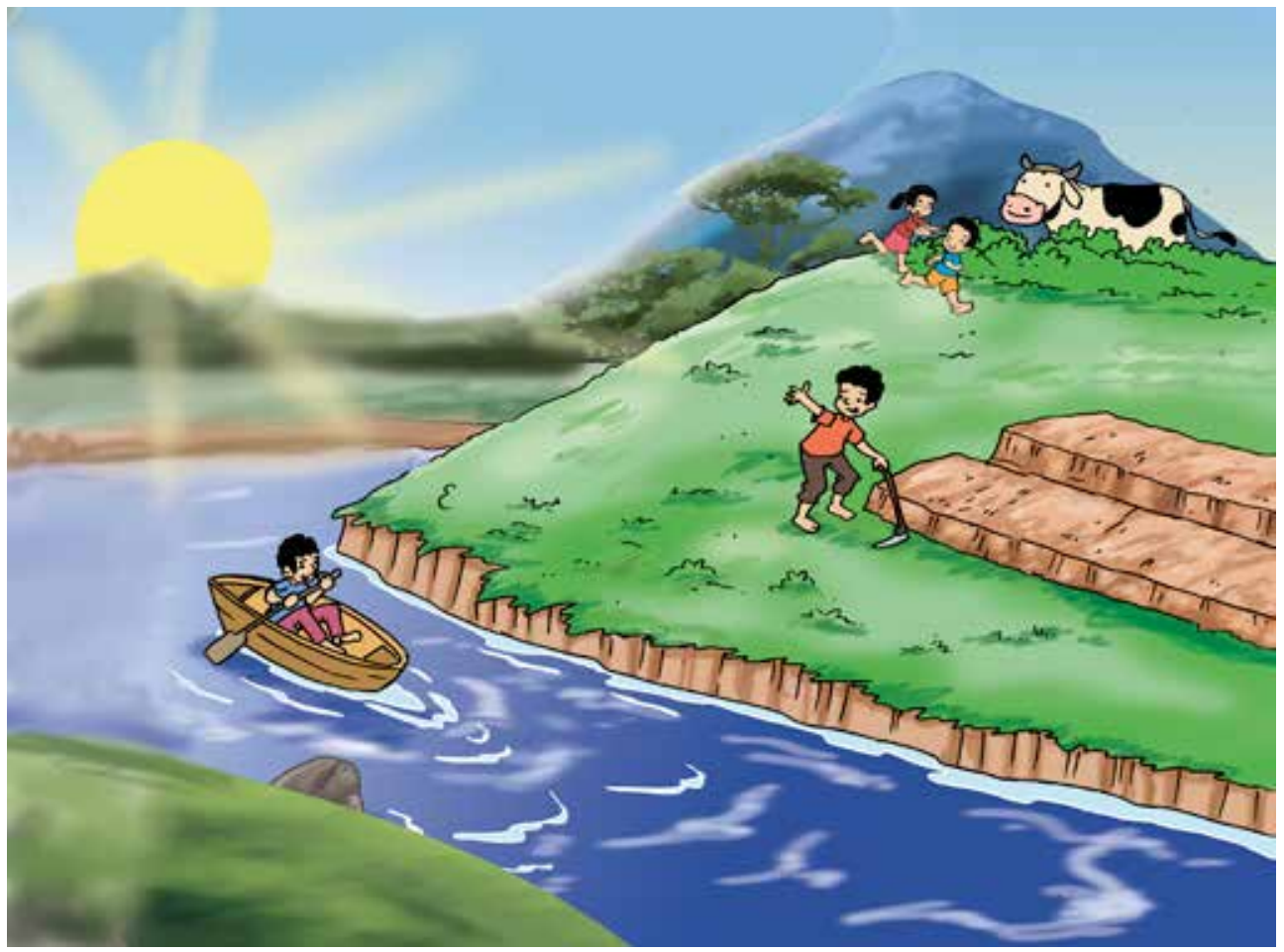


bodies) relationships provides a good foundation for developing processes for engaging communities in collaborative land use decision-making practices.

Experiences from CoLUPSIA offer the following generic lessons that will be of use to those undertaking similar socio-economic surveys in the future.

- Survey timing is important. Conducting surveys during planting season may be problematic as villagers are very busy. To deal with this issue, the CoLUPSIA team politely invited villagers to take part in a short interview in the evening and, where necessary, to continue the interview in the early morning. Alternatively, interviews were scheduled after villagers arrived home from their farm. It is also difficult to gather people and conduct focus group discussions during planting season. Similar problems arise if visiting villages during the harvest time, when village celebrations may be taking place.

- Incentives as compensation. In some circumstances, those participating in the survey work may expect to receive an incentive (e.g. money) from the project. Hence, it is important to explain to the community at the beginning of the survey whether or not there are any incentives.

- In planning the interview process, it is important to consider the time available and the most appropriate techniques for asking questions. Maintaining the interest of those being interviewed can be challenging, especially if the survey is very lengthy. Two hours is the maximum time for an interview, but if the interviewee loses interest, then the survey may be completed early. Use simple and clear terms, preferably in the local dialect or language, when asking questions.

- Checking the information collected. The team leader together with the team members should check all completed data before leaving the village. This will avoid the problem, which can often arise, of information being found to be incomplete only after the team has left the village and in some cases returned to their office.

\section{Methodology used by the CoLUPSIA team}

The overall objective of the study was to understand the socio-economic factors affecting the use patterns of natural resources at the district level. The project worked closely with local universities and NGOs. Surveys were completed for 19 villages and 30 households per village in Central Maluku, and 20 villages and 40 households per village in Kapuas Hulu. The households were randomly selected using a systematic random sampling method. The project collected data through household surveys, focus group discussions and interviews with key informants. 




Figure 2. Study villages in the four pilot areas in Kapuas Hulu, West Kalimantan

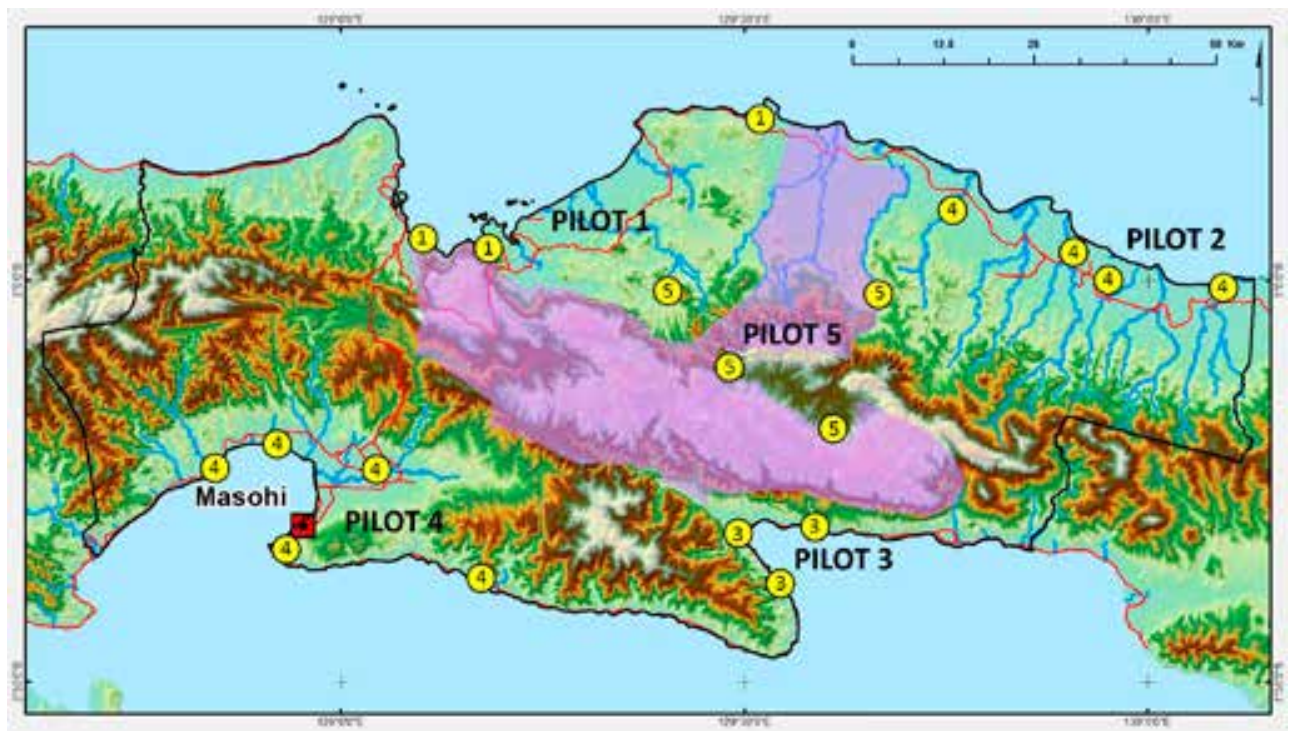

Figure 3. Study villages in the five pilot areas in Central Maluku (Seram Island), Maluku 
The survey used two questionnaires: village and household questionnaires. Village questionnaires were used for key informants such as village heads and traditional leaders to obtain overarching information about their villages and issues related to forest management, history of conflicts and the local point of view with regard to natural resource use. Household questionnaires were used for household interviews to gather information on demographics, economic activities and perceptions regarding tenure security and resource use.

Focus group discussions were also conducted to discuss tenure issues. The groups were selected based on gender, age and diversity of ethnic composition. Guidelines for conducting the focus group discussions were prepared, covering property rights, tenure security, forest management, conflicts/threats and community perceptions of their resources.

\section{Information requirements}

As outlined in the Socio-economic Guidelines, a survey should be designed so as to ensure that the information gathered meets the overall objective of the survey. For example, if the survey is about land use, then the questions should reflect this objective. The survey should not aim to gather all possible socio-economic information but rather should be targeted to the specific survey objective. This will ensure that the survey results are targeted and the survey can be undertaken in a reasonable time period. Table 5 provides some examples of the types of data that can be collected and the most appropriate means for collecting the information for use in collaborative land use planning. 
Table 5. Socio-economic data required for collaborative land use planning






\section{Resources}

Abdrabo, M.A. and M.A. Hassaan. 2003. From river catchments areas to the sea: comparative and integrated approach to the ecology of Mediterranean coastal zones for sustainable management (MEDCORE). A manual for socioeconomic study. Centre for Environment and Development for the Arab Region and Europe (CEDARE).

Colfer, C.J.P., M.A. Brocklesby, C. Diaw, P. Etuge, M. Günter, E. Harwell, C. McDougall, N.M. Porro, R. Porro, R. Prabhu. 1999. The BAG: basic assessment guide for human well-being. The criteria $\&$ indicator toolbox series No. 5. CIFOR, Bogor, Indonesia.

Dawson, S., and L. Manderson. 1993. A manual for the use of focus groups. Methods for social research in disease. International Nutrition Foundation for Developing Countries (INFDC), Boston, MA, USA.

De Brune and R. Santoso. 1998. Socio-economic for land use planning. FIMP-BPKP Technical Series No. 11.

Food and Agriculture Organization of the United Nations (FAO). 2002. FAO land tenure studies 3: land tenure and rural development. FAO, Rome.

Glaser, B.G. and A.L. Strauss. 1967. The Discovery of Grounded Theory: Strategies for Qualitative Research, Chicago, Aldine Publishing Company.

Leroy-Iskandar, C. and R. Santoso. 2002. Socio-economic for land use planning 1: general issues and methodologies. FIMP-BPKP Technical Series No. 20.

Liswanti, N. and I. Basuki. 2009. Guidelines for adapted Multidisciplinary Landscape Assessment methods for fire management project in India. CIFOR, Bogor, Indonesia.

Markelova, H. 2012. Report on the findings from the focus group discussion surveys and key informant interviews for the 'Collaborative land use planning and sustainable institutional arrangements for strengthening land tenure, forest, and community right in Indonesia. CoLUPSIA project. Bogor, Indonesia.

Mendenhall, W., R.J. Beaver and B.M. Beaver. 2003. Introduction to Probability and Statistics. $11^{\text {th }}$ Edn., Brooks/Cole, USA.

NVivo 9. 2010. NVivo qualitative data analysis software Version 9, 2010. QSR International Pty Ltd.

Roche, R. 2007. Livelihoods approaches as a conservation tool. IGERT Program. University of Rhode Island. Kingston, RI, USA. 
Shantiko, B., Y. Andries, B. Morialkosu and D. Amarduan. 2004. Socio economic analysis of rural Tanimbar. Tanimbar Land Use Planning Project. Technical Series No. 3. Jakarta.

Sheil, D. and N. Liswanti. 2006. Scoring the importance of tropical forest landscapes with local people: Patterns and insights. Environmental Management 38:126-136.

Sheil, D., R.K. Puri, I. Basuki, M. van Heist, M. Wan, N. Liswanti, Rukmiyati, M.A. Agung Sardjono, I. Samsoedin, K. Sidiyasa. 2003. Exploring biological diversity, environment and local people's perspectives in forest landscapes. Methods for a multidisciplinary landscape assessment. 2nd edition. CIFOR, Bogor, Indonesia.

Turell, G., C. Patterson, B. Oldenburg, T. Gould and M.A. Roy. 2003. The socio-economic patterning of survey participation and non-response error in multilevel study of food purchasing behavior: area and individual level characteristics. Public Health Nutrition 6:181-89.

Varkevisser, C., I. Pathmanathan and A. Brownlee. 2003. Designing and conducting health system research projects. Volume 1: proposal development and fieldwork. World Health Organization/International Development Research Centre. KIT Publishers, Amsterdam.

\section{Websites}

Badan Pusat Statistik (BPS) (Indonesia’s Central Statistics Agency):

http://www.bps.go.id

CoLUPSIA: http://www.colupsia.org/ 

This publication contains preliminary or advance research results, significant to tropical forest issues, that need to be published in a timely manner. They are produced to inform and promote discussion. Their content has been internally reviewed but has not undergone the lengthier process of external peer review.

Socio-economic survey tools provide a means of improving understanding of local resource management systems, resource use and the relative importance of resources for households and villages. They can also be used to elicit insights on interaction with government decision-making systems, community perceptions of trends and priority issues, and community-based institutions and their role in the sustainable use and conservation of natural resources. Use of such tools is an important first step in engaging local communities and ensuring that local voices are heard and that the community relationship with resources, land rights and access are incorporated into collaborative land use planning processes.

Collaborative land use planning involves working with all stakeholders - government, communities, the private sector and others - to ensure that land is used sustainably and that environmental degradation and forest loss are avoided, while accounting for the social and economic implications for all users. With respect to communities, collaborative land use planning aims:

To ensure that land use planning decisions are made with consideration of local communities' opinions, land use needs and socio-economic conditions, including rights of access to and use of land.

The aim of this guide (and the Supporting Notes) is to provide practical steps (survey design, sampling and data requirements; planning and training, conducting the survey) for field-based practitioners to conduct socio-economic surveys of households and villages, including focus groups and key informant interviews. The information obtained can be used directly in the collaborative land use planning process, helping to facilitate or reinforce a consensus on land tenure and rights, now and in the future.

This research was carried out as part of the European Union funded Collaborative Land Use Planning and Sustainable
Institutional Arrangement project. Run by CIRAD in partnership with CIFOR, TELAPAK and several local NGOs and
Universities, the project aims to contribute to avoided environmental degradation and to strengthen land tenure
and community right by collaboratively integrating all stakeholders' views in land use planning processes. The
outputs revolve around the relationship between land use planning, land allocation and the provision and potential
payment of ecosystem services. The project focuses on two regencies (kabupaten), Kapuas Hulu and Central Maluku
in Indonesia
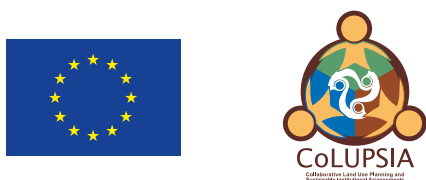

Center for International Forestry Research

CIFOR advances human wellbeing, environmental conservation and equity by conducting research to inform policies and practices that affect forests in developing countries. CIFOR is a CGIAR Consortium Research Center. CIFOR's headquarters are in Bogor, Indonesia. It also has offices in Asia, Africa and South America.

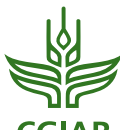

